\title{
Products of Sulfide/Selenite Interaction Possess Antioxidant Properties, Scavenge Superoxide-Derived Radicals, React with DNA, and Modulate Blood Pressure and Tension of Isolated Thoracic Aorta
}

\author{
Marian Grman, ${ }^{1}$ Anton Misak, ${ }^{1}$ Lucia Kurakova, ${ }^{2}$ Vlasta Brezova, ${ }^{3}$ Sona Cacanyiova ${ }^{\mathbb{D}},{ }^{4}$ \\ Andrea Berenyiova, ${ }^{4}$ Peter Balis $\mathbb{D}^{4}{ }^{4}$ Lenka Tomasova, ${ }^{1}$ Ammar Kharma, ${ }^{1}$ \\ Enrique Domínguez-Álvarez, ${ }^{5}$ Miroslav Chovanec $\mathbb{D}^{6},{ }^{6}$ and Karol Ondrias $\mathbb{D}^{1}$ \\ ${ }^{1}$ Institute of Clinical and Translational Research, Biomedical Research Center, Slovak Academy of Sciences, Dubravska cesta 9, \\ 84505 Bratislava, Slovakia \\ ${ }^{2}$ Department of Pharmacology and Toxicology, Faculty of Pharmacy, Comenius University, Odbojarov 10, 83232 Bratislava, Slovakia \\ ${ }^{3}$ Faculty of Chemical and Food Technology, Slovak University of Technology, Radlinskeho 9, 81237 Bratislava, Slovakia \\ ${ }^{4}$ Institute of Normal and Pathological Physiology, Centre of Experimental Medicine, Slovak Academy of Sciences, Dubravska cesta 9 , \\ 84104 Bratislava, Slovakia \\ ${ }^{5}$ Instituto de Química Orgánica General, Consejo Superior de Investigaciones Científicas (IQOG-CSIC), 28006 Madrid, Spain \\ ${ }^{6}$ Cancer Research Institute, Biomedical Research Center, Slovak Academy of Sciences, Dubravska cesta 9, 84505 Bratislava, Slovakia
}

Correspondence should be addressed to Miroslav Chovanec; miroslav.chovanec@savba.sk and Karol Ondrias; karol.ondrias@savba.sk

Received 27 June 2019; Accepted 12 September 2019; Published 25 November 2019

Guest Editor: Kyoung Soo Kim

Copyright ( 2019 Marian Grman et al. This is an open access article distributed under the Creative Commons Attribution License, which permits unrestricted use, distribution, and reproduction in any medium, provided the original work is properly cited.

Selenium (Se), an essential trace element, and hydrogen sulfide $\left(\mathrm{H}_{2} \mathrm{~S}\right)$, an endogenously produced signalling molecule, affect many physiological and pathological processes. However, the biological effects of their mutual interaction have not yet been investigated. Herein, we have studied the biological and antioxidant effects of the products of the $\mathrm{H}_{2} \mathrm{~S}\left(\mathrm{Na}_{2} \mathrm{~S}\right) / \mathrm{selenite}$ $\left(\mathrm{Na}_{2} \mathrm{SeO}_{3}\right)$ interaction. As detected by the UV-VIS and EPR spectroscopy, the product(s) of the $\mathrm{H}_{2} \mathrm{~S}-\mathrm{Na}_{2} \mathrm{SeO}_{3}$ and $\mathrm{H}_{2} \mathrm{~S}-\mathrm{SeCl}$ interaction scavenged superoxide-derived radicals and reduced cPTIO radical depending on the molar ratio and the preincubation time of the applied interaction mixture. The results confirmed that the transient species are formed rapidly during the interaction and exhibit a noteworthy biological activity. In contrast to $\mathrm{H}_{2} \mathrm{~S}$ or selenite acting on their own, the $\mathrm{H}_{2} \mathrm{~S}$ /selenite mixture cleaved DNA in a bell-shaped manner. Interestingly, selenite protected DNA from the cleavage induced by the products of $\mathrm{H}_{2} \mathrm{~S} / \mathrm{H}_{2} \mathrm{O}_{2}$ interaction. The relaxation effect of $\mathrm{H}_{2} \mathrm{~S}$ on isolated thoracic aorta was eliminated when the $\mathrm{H}_{2} \mathrm{~S}$ /selenite mixture was applied. The mixture inhibited the $\mathrm{H}_{2} \mathrm{~S}$ biphasic effect on rat systolic and pulse blood pressure. The results point to the antioxidant properties of products of the $\mathrm{H}_{2} \mathrm{~S} /$ selenite interaction and their effect to react with DNA and influence cardiovascular homeostasis. The effects of the products may contribute to explain some of the biological effects of $\mathrm{H}_{2} \mathrm{~S}$ and/or selenite, and they may imply that a suitable $\mathrm{H}_{2} \mathrm{~S}$ /selenite supplement might have a beneficial effect in pathological conditions arisen, e.g., from oxidative stress. 


\section{Introduction}

Exogenously added and endogenously produced $\mathrm{H}_{2} \mathrm{~S}$ affects many physiological and pathological processes [1-3]. Accumulating evidence supports the involvement of $\mathrm{H}_{2} \mathrm{~S}$ in the regulation of cardiovascular homeostasis [4]. It has mostly beneficial effects during oxidative stress by reacting with reactive oxygen and nitrogen species, i.e., hydrogen peroxide $\left(\mathrm{H}_{2} \mathrm{O}_{2}\right)$, superoxide anion radical $\left(\mathrm{O}_{2}{ }^{--}\right)$, hypochlorite $(\mathrm{HOCl})$, or peroxynitrite $\left(\mathrm{ONOO}^{-}\right)$[5-8]. However, several effects of $\mathrm{H}_{2} \mathrm{~S}$ on cells are toxic [9-11].

Selenium (Se) is a relatively rare but an essential trace element for humans, plants, and microorganisms. Se, which exerts multiple and complex effects on human health, is known as an antioxidant due to its presence in 25 selenoproteins in the form of selenocysteine amino acid. Both beneficial and detrimental effects of Se deficiency and/or supplementation are well known. The biological effects of Se compounds (selenite, selenate, selenocysteine, and selenomethionine) on cardiac oxidative damage, heart disease, cancer prevention, immunity, diabetes, neuroregeneration, or dementia have been reported [12-17]. However, the beneficial effect of Se supplementation for men's health is still a controversial issue [18-23]. Selenite, which is a common Se supplement, is considered as a promising anticarcinogen [24-26]. It can induce apoptosis in cancer cells through the production of reactive oxygen species (ROS) leading to oxidative stress $[27,28]$. However, Se compounds were also found to damage DNA in healthy cells [29] and therefore may not be considered as a suitable protective agent against cancer and/or other chronic diseases. Actually, they can cause or advance some kinds of cancers [30, 31]. The exact mechanisms of the beneficial and toxic effects of Se are not yet fully understood, giving rise to further uncertainty about its potential use in nutrition supplements and/or clinical treatment.

Se and $\mathrm{H}_{2} \mathrm{~S}$ are present in living organisms, and each one has beneficial and/or toxic effects through its interaction mostly with ROS [1, 2, 30-33]. However, the biological effects of products of the $\mathrm{H}_{2} \mathrm{~S}$ /selenite interaction are not yet known, namely, their involvement in the production and/or inhibition of ROS, reaction with DNA, or influence on cardiovascular system. Therefore, we have studied the effects of products of the $\mathrm{H}_{2} \mathrm{~S}$ /selenite interaction on $\mathrm{O}_{2}{ }^{-}$ and 'cPTIO radicals, DNA cleavage, tension of isolated aortic rings, and rat blood pressure (BP). We found that the products have significant biological effects that differ from those caused by $\mathrm{H}_{2} \mathrm{~S}$ or by selenite on their own. These results may contribute to the understanding of possible coupled biological effects of $\mathrm{H}_{2} \mathrm{~S}$ and Se.

\section{Material and Methods}

\subsection{Chemicals}

2.1.1. Selenium Compounds. Stock solutions of sodium selenite $\left(\mathrm{Na}_{2} \mathrm{SeO}_{3}, 10\right.$ or $40 \mathrm{mmol} \mathrm{L}^{-1}$, Merck K34993707542 or Sigma 214485), selenium tetrachloride $\left(\mathrm{SeCl}_{4}, 10\right.$ mmol L ${ }^{-1}$, Aldrich 323527), and sodium selenate $\left(\mathrm{Na}_{2} \mathrm{SeO}_{4}\right.$,
$10 \mathrm{mmol} \mathrm{L}^{-1}$, Sigma S0882) were prepared freshly in deionized $\mathrm{H}_{2} \mathrm{O}$, stored at $23^{\circ} \mathrm{C}$, and used within $5 \mathrm{~h} . \mathrm{Na}_{2} \mathrm{SeO}_{3}$ dissociates in solution to yield mostly $\mathrm{H}_{2} \mathrm{SeO}_{3}$ at acidic $\mathrm{pH}$, $\mathrm{HSeO}_{3}{ }^{-}$at neutral $\mathrm{pH}$, and $\mathrm{SeO}_{3}{ }^{2-}$ at alkaline $\mathrm{pH}$. For simplicity, the term $\mathrm{SeO}_{3}{ }^{2-}$ is employed as representative expression to encompass the total mixture of these different (de)protonation states.

2.1.2. Hydrogen Peroxide. Hydrogen peroxide $\left(\mathrm{H}_{2} \mathrm{O}_{2}\right)$ (14.7 $\mathrm{mol} \mathrm{L}^{-1}$; Sigma-Aldrich 85321 ), according to a particular experiment, was diluted in $\mathrm{H}_{2} \mathrm{O}$ or in $100 \mathrm{mmol} \mathrm{L}^{-1}$ sodium phosphate buffer, supplemented with 200 or $50 \mu \mathrm{mol} \mathrm{L}{ }^{-1} \mathrm{DTPA}, \mathrm{pH} 7.4,37^{\circ} \mathrm{C}$ before application.

2.1.3. Radicals. 5-tert-butoxycarbonyl-5-methyl-1-pyrroline$N$-oxide (BMPO, $100 \mathrm{mmol} \mathrm{L}^{-1}$, Dojindo B568-10, Japan) was dissolved in deionized $\mathrm{H}_{2} \mathrm{O}$, stored at $-80^{\circ} \mathrm{C}$, and used after thawing. 2-(4-Carboxyphenyl)-4,4,5,5-tetramethylimidazoline-1-oxyl-3-oxide (cPTIO, $10 \mathrm{mmol} \mathrm{L}^{-1}$, Cayman 81540 or Sigma C221) was dissolved in deionized $\mathrm{H}_{2} \mathrm{O}$ and was stored at $-20^{\circ} \mathrm{C}$ for several weeks.

2.1.4. Sulfide. $\mathrm{Na}_{2} \mathrm{~S}\left(100 \mathrm{mmol} \mathrm{L}^{-1}\right.$ stock solution, Dojindo SB01, Japan) was dissolved in argon degassed deionized $\mathrm{H}_{2} \mathrm{O}$, stored at $-80^{\circ} \mathrm{C}$, and used immediately after thawing. $\mathrm{Na}_{2} \mathrm{~S}$ dissociates in aqueous solution and reacts with $\mathrm{H}^{+}$to yield $\mathrm{H}_{2} \mathrm{~S}, \mathrm{HS}^{-}$, and a trace of $\mathrm{S}^{2-}$. We use the term $\mathrm{H}_{2} \mathrm{~S}$ to describe the total mixture of $\mathrm{H}_{2} \mathrm{~S}, \mathrm{HS}^{-}$, and $\mathrm{S}^{2-}$ forms. The stock concentration was checked by UV-VIS spectroscopy: by the absorbance of $1000 \mathrm{x}$ diluted stock solution at $230 \mathrm{~nm}\left(\varepsilon_{230 \mathrm{~nm}}=7700 \mathrm{~mol}^{-1} \mathrm{~L} \mathrm{~cm}^{-1}\right.$, diluted by deionized water) and also by the reduction of $100 \mu \mathrm{mol} \mathrm{L}{ }^{-1}$ DTNB by 2000x diluted stock solution $\left(1 \mathrm{H}_{2} \mathrm{~S}\right.$ molecule generates 2 TNB ${ }^{-}$equivalents, $\varepsilon_{412 \mathrm{~nm}}=14,100 \mathrm{~mol}^{-1} \mathrm{~L} \mathrm{~cm}^{-1}$, measured in $1 \mathrm{mmol} \mathrm{L}^{-1}$ phosphate buffer), according to Nagy et al. [34].

2.1.5. Buffers. $100 \mathrm{mmol} \mathrm{L}^{-1}$ sodium phosphate buffer supplemented with $100 \mu \mathrm{mol} \mathrm{L}{ }^{-1}$ diethylenetriaminepentaacetic acid (DTPA), pH6.5, 7.0, 7.4, 8.0, and 9.0, $37^{\circ} \mathrm{C}$, was employed for UV-VIS experiments. 50 and $25 \mathrm{mmol} \mathrm{L}^{-1}$ sodium phosphate buffer, supplemented with 100 and $50 \mu \mathrm{mol} \mathrm{L}{ }^{-1} \mathrm{DTPA}, \mathrm{pH} 7.4,37^{\circ} \mathrm{C}$, was used for electron paramagnetic resonance (EPR) and plasmid DNA (pDNA) cleavage studies, respectively.

2.2. UV-VIS of 'cPTIO. To obtain $1 \mathrm{~mL}$ of the working solution, 10 or $100 \mu \mathrm{L}$ of stock solution of the compounds studied was added to the appropriate volume (990 or $900 \mu \mathrm{L}$, respectively) of $100 \mathrm{mmol} \mathrm{L}^{-1}$ sodium phosphate buffer (at given $\mathrm{pH}, 37^{\circ} \mathrm{C}$ ) containing the final concentrations of $100 \mu \mathrm{mol} \mathrm{L}^{-1}{ }_{\mathrm{CPTIO}}$ and $100 \mu \mathrm{mol} \mathrm{L}^{-1}$ DTPA. UV-VIS absorption spectra $(900-190 \mathrm{~nm})$ were recorded every $30 \mathrm{~s}$ for 20 to $40 \mathrm{~min}$ with a Shimadzu 1800 (Kyoto, Japan) spectrometer at $37^{\circ} \mathrm{C}$. The ${ }^{\circ} \mathrm{PTTIO}$ extinction coefficient of $920 \mathrm{~mol}^{-1} \mathrm{~L} \mathrm{~cm}^{-1}$ at $560 \mathrm{~nm}$ was used. The reduction of the $\mathrm{CPTIO}$ radical was determined as the decrease of the absorbance at $560 \mathrm{~nm}$ (absorption maximum of ${ }^{\circ}$ PTIO in VIS range) or at $358 \mathrm{~nm}$ after subtracting the absorbances at 730 or at $420 \mathrm{~nm}$, respectively $[5,35]$. 
To study the involvement of $\mathrm{O}_{2}$ in the $\mathrm{H}_{2} \mathrm{~S}_{2} \mathrm{SeO}_{3}{ }^{2-}$-induced reduction of the cPTIO radical, $10 \mathrm{mmol} \mathrm{L}^{-1} \mathrm{Na}_{2} \mathrm{~S}$ in $\mathrm{H}_{2} \mathrm{O}$, $10 \mathrm{mmol} \mathrm{L}^{-1} \mathrm{Na}_{2} \mathrm{SeO}_{3}$ in $\mathrm{H}_{2} \mathrm{O}$, and $102 \mu \mathrm{mol} \mathrm{L}^{-1}{ }_{\mathrm{cPTIO}}$ in the $100 \mathrm{mmol} \mathrm{L}^{-1}$ sodium phosphate buffer, supplemented with $100 \mu \mathrm{mol} \mathrm{L}^{-1}$ DTPA $\left(\mathrm{pH} 7.4 ; 37^{\circ} \mathrm{C}\right)$, were deaerated with argon for $10 \mathrm{~min}$ at $37^{\circ} \mathrm{C}$. The compounds were mixed in a closed UV-cuvette, and the UV-VIS spectra were recorded. The $\mathrm{O}_{2}$ concentration in the deaerated samples was 3-5\%, confirmed with an oxygen electrode (OXELP, SYS-ISO2, WPI, USA). In all UV-VIS experiments, $\mathrm{H}_{2} \mathrm{O}$ was used as a blank.

2.3. EPR of the BMPO Adducts. To study the ability of $\mathrm{H}_{2} \mathrm{~S} \mathrm{SeO}_{3}{ }^{2-}$ to scavenge the $\mathrm{O}_{2}^{--}$radical or its derivatives produced in $\mathrm{DMSO} / \mathrm{KO}_{2}$ solution, sample preparation and EPR measurements were conducted in accordance with previously reported protocols [5]. The solution (final concentrations) of BMPO $\left(20 \mathrm{mmol} \mathrm{L}^{-1}\right)$, DTPA $\left(100 \mu \mathrm{mol} \mathrm{L}^{-1}\right)$ in sodium phosphate buffer $\left(50 \mathrm{mmol} \mathrm{L}^{-1}, \mathrm{pH} 7.4\right)$ was incubated for $1 \mathrm{~min}$ at $37^{\circ} \mathrm{C}$; an aliquot of the compound was added, followed by saturated $\mathrm{KO}_{2} / \mathrm{DMSO}$ solution (10\% $v / v$ DMSO/final buffer) $3 \mathrm{~s}$ later. The sample was mixed for $5 \mathrm{~s}$ and transferred to a standard cavity aqueous EPR flat cell. The first EPR spectrum was recorded $2 \mathrm{~min}$ after the addition of $\mathrm{KO}_{2} / \mathrm{DMSO}$ solution at $37^{\circ} \mathrm{C}$. The sets of individual EPR spectra of the BMPO spin adducts were recorded as 15 sequential scans, each $42 \mathrm{~s}$, with a total time of $11 \mathrm{~min}$. Each experiment was repeated at least twice. EPR spectra of the BMPO spin adducts were measured on a Bruker EMX spectrometer, X-band $\sim 9.4 \mathrm{GHz}, 335.15 \mathrm{mT}$ central field, $8 \mathrm{mT}$ scan range, $20 \mathrm{~mW}$ microwave power, 0.1 or $0.15 \mathrm{mT}$ modulation amplitude, $42 \mathrm{~s}$ sweep time, $20.48 \mathrm{~ms}$ time constant, and $20.48 \mathrm{~ms}$ conversion time at $37^{\circ} \mathrm{C}$. Intensities of the BMPO adducts in the EPR spectra were reproducible, when the $\mathrm{KO}_{2} / \mathrm{DMSO}$ stock solution was stored at $5^{\circ} \mathrm{C}$ for 1 day or at $23 \pm 1^{\circ} \mathrm{C}$ for $4 \mathrm{~h}$.

2.4. Plasmid DNA Cleavage. pDNA cleavage assay with the use of pBR322 plasmid (New England BioLabs Inc., N3033L) was performed as reported previously $[5,36]$. In this assay, all samples contained $0.2 \mu \mathrm{g}$ pDNA in sodium phosphate buffer $\left(25 \mathrm{mmol} \mathrm{L}^{-1}\right.$ sodium phosphate, $50 \mu \mathrm{mol} \mathrm{L}^{-1}$ DTPA, $\left.\mathrm{pH} 7.4,37^{\circ} \mathrm{C}\right)$. After addition of compounds, the resulting mixtures were incubated for $30 \mathrm{~min}$ at $37^{\circ} \mathrm{C}$. All concentrations listed in the section were final in the samples. After incubation, the reaction mixtures were subjected to $0.6 \%$ agarose gel electrophoresis. Samples were electrophoresed in TBE buffer $\left(89 \mathrm{mmol} \mathrm{L}^{-1}\right.$ Tris, $89 \mathrm{mmol} \mathrm{L}^{-1}$ boric acid, and $2 \mathrm{mmol} \mathrm{L}^{-1}$ EDTA) at $5.5 \mathrm{~V} \mathrm{~cm}^{-1}$ for $2 \mathrm{~h}$; gels were stained with GelRed ${ }^{\mathrm{TM}}$ Nucleic Acid Gel Stain and photographed using a UV transilluminator. Integrated densities of all pBR322 forms in each lane were quantified using the TotalLab TL100 image analysis software to estimate pDNA cleavage efficiency (Nonlinear Dynamic Ltd., USA).

\subsection{Guide for the Use and Care of Laboratory Animals}

2.5.1. Isolated Thoracic Aorta. Procedures were performed in accordance with the Institutional Guidelines of the Eth- ical Committee on the Ethics of Procedures in Animal, Clinical and other Biomedical Experiments (permit number: EC/CEM/2017/4) of the Institute of Normal and Pathological Physiology, Centre of Experimental Medicine and were approved by the State Veterinary and Food Administration of the Slovak Republic and by an Ethical Committee according to the European Convention for the Protection of Vertebrate Animals used for Experimental and other Scientific Purposes, Directive 2010/63/EU of the European Parliament. The Institute of Normal and Pathological Physiology provided veterinary care.

2.5.2. Rat Blood Pressure. All procedures were approved by the State Veterinary and Food Administration of the Slovak Republic (No.: Ro-1545/15-221) according to the guidelines from Directive 2010/63/EU of the European Parliament. Experiments were carried out according to the guidelines laid down by the animal welfare committee of the Institute of Normal and Pathological Physiology of the Slovak Academy of Sciences and conformed to the principles and regulations, as described in the editorial by Grundy [37].

2.6. Functional Study of Isolated Thoracic Aorta. Normotensive Wistar Kyoto (WKY) rats $(307 \pm 4.3 \mathrm{~g})$ were killed by decapitation after a brief anesthetization with $\mathrm{CO}_{2}$, and the thoracic aorta was isolated as described in our previous study [38]. The changes in isometric tension were measured by the electromechanical transducers (FSG-01, MDE, Budapest, Hungary). The resting tension of $1 \mathrm{~g}$ was applied to each ring and maintained throughout a 45 to $60 \mathrm{~min}$ of equilibration period until stress relaxation no longer occurred. Changes in thoracic aorta tension were followed by noradrenaline (NA; $1 \mu \mathrm{mol} \mathrm{L}^{-1}$ ) precontracted arterial rings after a stable plateau was achieved.

2.7. Functional Study of Rat Blood Pressure. Male Wistar rats $(n=10 ; 350 \pm 40 \mathrm{~g})$ were from the Department of Toxicology and Laboratory Animal Breeding at Dobra Voda, Slovak Academy of Sciences, Slovakia. The rats were housed under a $12 \mathrm{~h}$ light $-12 \mathrm{~h}$ dark cycle, at a constant humidity (45$65 \%)$ and temperature $\left(20-22^{\circ} \mathrm{C}\right)$, with free access to standard laboratory rat chow and drinking water. The Institute of Experimental Pharmacology and Toxicology, Centre of Experimental Medicine, Slovak Academy of Sciences, provided veterinary care. The tranqualizer xylazine (Rometar) was purchased from Zentiva (Czech Republic), and the anesthetic combination of tiletamine+zolazepam (Zoletil 100) was acquired from Virbac (France). All other chemicals were purchased from Sigma-Aldrich. Experiments were carried out as previously described [39]. Rats were anesthetized with Zoletil 100 (tiletamine+zolazepam, $80 \mathrm{mg} \mathrm{kg}^{-1}$, i.p.) and Rometar (xylazine, $5 \mathrm{mg} \mathrm{kg}^{-1}$, i.p.). During the anesthesia, $\mathrm{BP}$, heart rate, and reflex responses to mechanical stimuli were monitored. The animals were under anesthesia during the whole experiment and were euthanized with an overdose of Zoletil via jugular vein at the end of the surgical procedure. All experiments were supervised and performed under the same experimental conditions. 
2.8. Blood Pressure Measurement. The right jugular vein was cannulated to administer compounds under anesthesia as described above. The left arteria carotis communis was cannulated for inserting the fiber optic microcatheter pressure transducers (FISO LS 2F Harvard Apparatus, USA). The analog signal was digitalized at $10 \mathrm{kHz}$, filtered at $1 \mathrm{kHz}$, and recorded by DEWESoft 6.6.7 ( $\mathrm{GmbH}$, Austria). The signal was evaluated $5 \mathrm{~s}$ before and $10 \mathrm{~min}$ after compound administration. After stabilization of BP (10-20 min), the compounds were administered into the right jugular vein as a bolus of $500 \mu \mathrm{L} \mathrm{kg}^{-1}$ over $15 \mathrm{~s}$ period. The solution of the $\mathrm{H}_{2} \mathrm{~S}_{\mathrm{SeO}}{ }^{2-}$ mixture $\left(10 / 5 \mathrm{in} \mathrm{mmol} \mathrm{\textrm {L } ^ { - 1 }}\right)$ was prepared as follows: to $123.5 \mu \mathrm{L}$ of $100 \mathrm{mmol} \mathrm{L}^{-1}$ phosphate buffer, $100 \mu \mathrm{mol} \mathrm{L}^{-1}$ DTPA, $14 \mu \mathrm{L}$ of $1 \mathrm{~mol} \mathrm{~L}^{-1} \mathrm{HCl}$ was added, followed by $62.5 \mu \mathrm{L}$ of $40 \mathrm{mmol} \mathrm{L}^{-1} \mathrm{Na}_{2} \mathrm{SeO}_{3}$ in $0.9 \% \mathrm{NaCl}$, and finally $50 \mu \mathrm{L}$ of $100 \mathrm{mmol} \mathrm{L}^{-1} \mathrm{Na}_{2} \mathrm{~S}$ in $\mathrm{H}_{2} \mathrm{O}$ was added. The $\mathrm{pH}$ of the buffered mixture was 7.4. The mixture was incubated for $40 \pm 10 \mathrm{~s}$ at $23^{\circ} \mathrm{C}$ before i.v. administration. Unbuffered $\mathrm{H}_{2} \mathrm{~S}_{/} \mathrm{SeO}_{3}{ }^{2-}$ mixture $\left(10 / 5\right.$ in $\left.\mathrm{mmol} \mathrm{L}^{-1}\right)$ was prepared, when $0.9 \% \mathrm{NaCl}$ was used instead of phosphate buffer and $\mathrm{HCl}$. The $\mathrm{pH}$ of the unbuffered mixture was $\sim 11$ measured by a $\mathrm{pH}$ paper indicator.

2.9. Statistical Analysis. Unless otherwise stated, data are represented as the means \pm S.E.M. Statistical significance was determined by Student's $t$-test or one-way ANOVA followed by the multiple comparison test. Differences between means were considered significant at ${ }^{*} P \leq 0.05$. Data analysis and plot construction were carried out using SigmaPlot 12 (Systat Software GmbH).

\section{Results}

3.1. $\mathrm{H}_{2} \mathrm{~S}$ Interacts with $\mathrm{Na}_{2} \mathrm{SeO}_{3}$ and $\mathrm{SeCl}_{4}$, but Not with $\mathrm{Na}_{2} \mathrm{SeO}_{4}$ to Form Initial Reactive Intermediate(s), which Reduce the 'CPTIO Radical. Since the antioxidant properties of $\mathrm{H}_{2} \mathrm{~S} / \mathrm{SeO}_{3}{ }^{2-}$ products are unknown, we have used the cPTIO radical to study the reducing properties of the products of $\mathrm{H}_{2} \mathrm{~S} / \mathrm{SeO}_{3}{ }^{2-}$ interaction. The cPTIO radical is stable in aqueous solution, and its formation and reduction can be monitored by the UV-VIS spectrophotometry at 358 or $560 \mathrm{~nm}$. Even in the presence of up to $100 \mu \mathrm{mol} \mathrm{L}^{-1} \mathrm{H}_{2} \mathrm{~S}$ or $100-400 \mu \mathrm{mol} \mathrm{L}^{-1} \mathrm{SeO}_{3}{ }^{2-}$, the absorbance (ABS) of the radical at 358 and $560 \mathrm{~nm}$ decreases only by $<7 \%$ after $40 \mathrm{~min}$, indicating that neither $\mathrm{H}_{2} \mathrm{~S}$ nor $\mathrm{SeO}_{3}{ }^{2-}$ on its own reduces this radical (Figure 1). In contrast, once

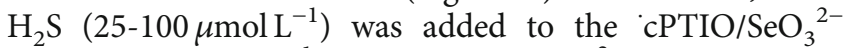
$\left(100 / 2.5-400 \mu \mathrm{mol} \mathrm{L}^{-1}\right)$ mixture, or $\mathrm{SeO}_{3}{ }^{2-}$ was added to cPTIO/ $\mathrm{H}_{2} \mathrm{~S}$, the absorbances at 358 and $560 \mathrm{~nm}$ decreased rapidly over the time $(\leq 30 \mathrm{~s})$, indicating a possible formation of strong reducing agent(s) which fastly and efficiently reduced the cPTIO radical (Figures 1 and 2). Similar results were obtained when $\mathrm{SeCl}_{4}$, but not $\mathrm{Na}_{2} \mathrm{SeO}_{4}$, was used instead of $\mathrm{SeO}_{3}{ }^{2-}$ (Figures $\mathrm{S} 1$ and S2a).

The reduction of " $\mathrm{PTTIO}$ followed a bell-shaped dependence on the concentration of $\mathrm{SeO}_{3}{ }^{2-}$ at a constant cPTIO/ $\mathrm{H}_{2} \mathrm{~S}$ concentration (Figure $2(\mathrm{a})$ ), with a maximum radical scavenging activity at an $\mathrm{H}_{2} \mathrm{~S}: \mathrm{SeO}_{3}{ }^{2-}$ ratio of roughly $4: 1$. The ability of $\mathrm{H}_{2} \mathrm{~S}$ to reduce ${ }^{\mathrm{cPTIO}}$ in the presence of
$\mathrm{SeO}_{3}{ }^{2-}$ increased with the increasing $\mathrm{H}_{2} \mathrm{~S}$ concentration (Figure 2(b)) and followed also a bell-shaped dependence on $\mathrm{pH}$ (Figures 3 and S3).

If $\mathrm{H}_{2} \mathrm{~S}$ and $\mathrm{SeO}_{3}{ }^{2-}$ were preincubated for different periods of time before the addition to cPTIO, it clearly resulted in the highest radical scavenging activity, which was subsequently lost over the time (Figure 4). An $\mathrm{H}_{2} \mathrm{~S} / \mathrm{SeO}_{3}{ }^{2-}\left(100 / 100\right.$ in $\left.\mu \mathrm{mol} \mathrm{L}^{-1}\right)$ mixture preincubated for $\geq 1 \mathrm{~min}$ prior to ${ }^{\mathrm{CPTIO}}$ addition did not reduce ${ }^{\mathrm{cPTIO}}$, demonstrating that later products of the reaction of sulfide with $\mathrm{SeO}_{3}{ }^{2-}$ could not be responsible for the reduction of the radical and that the relevant active species were formed swiftly, in less than $1 \mathrm{~min}$ and have a short lifetime, as recently suggested [40]. Notably, formation of these active early intermediates to reduce cPTIO was prolonged with the increase of the $\mathrm{H}_{2} \mathrm{~S}_{/} \mathrm{SeO}_{3}{ }^{2-}$ ratio (Figure 4(e)). At $\mathrm{H}_{2} \mathrm{~S} / \mathrm{SeO}_{3}{ }^{2-}$ concentration of $100 / 25$ in $\mu \mathrm{mol} \mathrm{L}^{-1}$ and $5 \mathrm{~min}$ preincubation time, the mixture still possessed around 50\% potency to reduce cPTIO (Figure 4(e)). This timing, once more, accounts for a rapidly formed selenosulfide intermediate as beeing the ultimate responsible for this radical scavenging activity, a species also possibly being sensitive to oxidation over prolonged time periods (Figure 4).

While the available evidence is in accordance with the formation of HSSeSH as the main reactive species, there are other chalcogen-based candidates which are good reducing agents, namely, hydrogen selenide $\left(\mathrm{H}_{2} \mathrm{Se}\right)$, hydroselenide anion $\left(\mathrm{HSe}^{-}\right)$, selenide $\left(\mathrm{Se}^{2-}\right)$, persulfides, and polysulfides $\left(\mathrm{S}_{x}^{2-}\right)$ [41-43]. Interestingly, $\mathrm{O}_{2}$ does not seem to play a major role in the $\mathrm{H}_{2} \mathrm{~S}_{/} \mathrm{SeO}_{3}{ }^{2-}$-induced reduction of the cPTIO radical probably due to slower kinetics of interaction of reactants and/or intermediates with $\mathrm{O}_{2}$ in comparison to the rate of 'CPTIO reduction [44-48]. Under argon flushed conditions, reduction of the cPTIO radical was neither enhanced nor suppressed significantly, hence ruling out any major involvement of $\mathrm{H}_{2} \mathrm{Se}$, as this selenium compound is highly sensitive to $\mathrm{O}_{2}$ (Figure S2b).

3.2. EPR of BMPO-OOH: The Initial Products of the $\mathrm{H}_{2} \mathrm{~S} / \mathrm{SeO}_{3}{ }^{2-}$ Interaction Also Scavenge Derivatives of Superoxide Anion $\left(\mathrm{O}_{2}^{-}\right)$Radical. We aimed to ascertain whether the initial products of the $\mathrm{H}_{2} \mathrm{~S}_{\mathrm{SeO}}{ }^{2-}$ interaction are able to scavenge other radicals, i.e., $\mathrm{O}_{2}{ }^{--}$or its derivatives. The interactions with $\mathrm{O}_{2}{ }^{-}$were studied with the EPR spin trap method based on the reaction of this dioxygen radical with BMPO to form the BMPO-OOH adduct [49]. This assay was chosen due to biological and mechanistical reason; $\mathrm{O}_{2}{ }^{--}$is a simple radical reduced by one-electron transfer.

$\mathrm{O}_{2}{ }^{--}$was dissolved in phosphate buffer $\left(\mathrm{pH} 7.4,37^{\circ} \mathrm{C}\right)$ and trapped by BMPO. Under these conditions, the relative intensity of the BMPO-OOH adduct decreased slowly over the time and was comparable to the values reported under physiological conditions (Figures 5(a1)-5(a3)) [49]. The addition of $\mathrm{SeO}_{3}{ }^{2-}\left(25\right.$ and $\left.50 \mu \mathrm{mol} \mathrm{L}^{-1}\right)$ did not significantly interfere with the $\mathrm{BMPO}-\mathrm{OOH}$ adduct formation, its concentration, and rate of decay (Figures 5(b1)-5(b3), S4b1-b3). In contrast, $\mathrm{H}_{2} \mathrm{~S}\left(25\right.$ and $\left.50 \mu \mathrm{mol} \mathrm{L}^{-1}\right)$ decreased the $\mathrm{BMPO}-\mathrm{OOH}$ concentration and increased the rate of the decay, and this "antioxidant" activity of $\mathrm{H}_{2} \mathrm{~S}$ was 


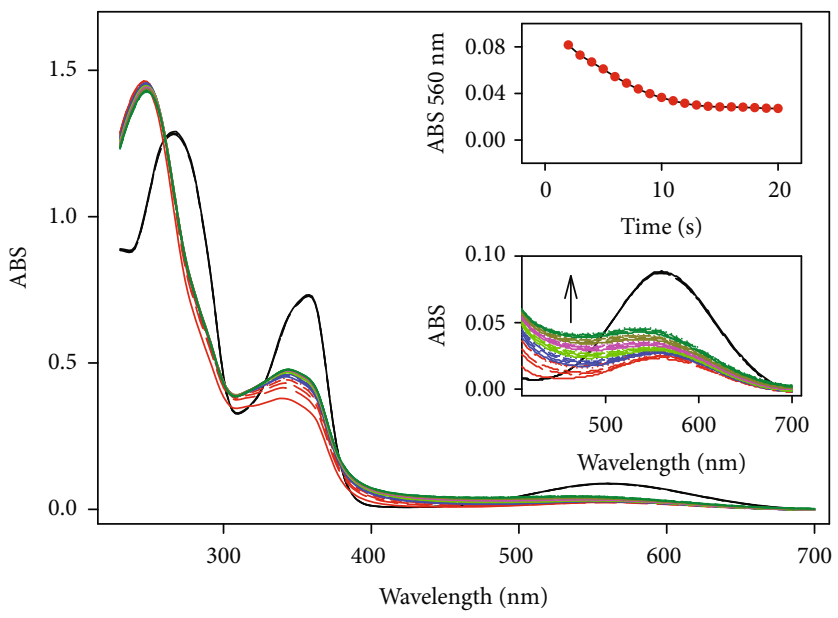

(a)

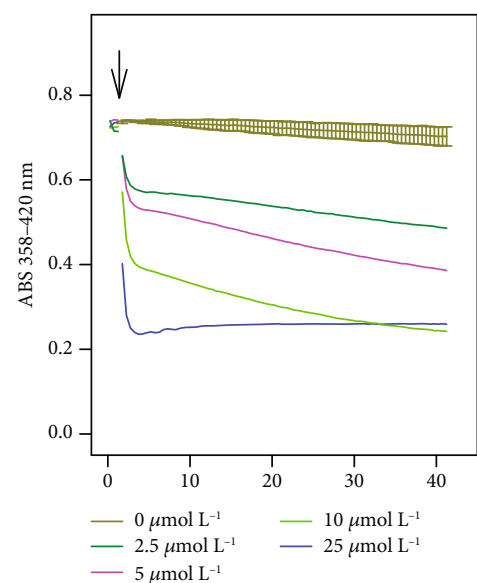

(b)

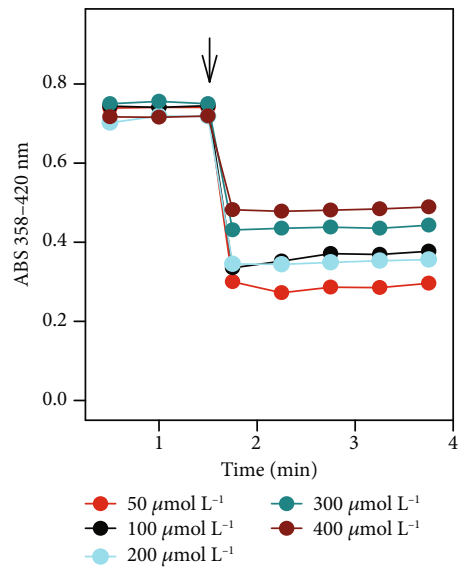

(d)

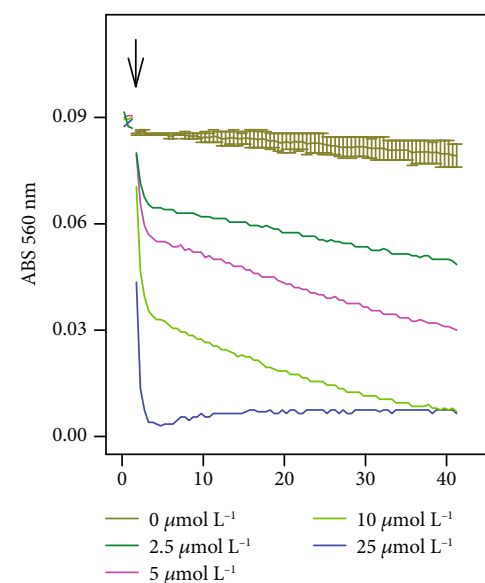

(c)

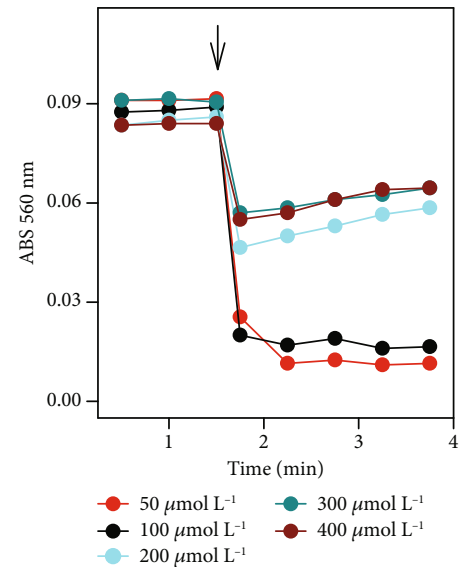

(e)

Figure 1: Interaction of ${ }^{\mathrm{c}} \mathrm{PTIO} / \mathrm{SeO}_{3}{ }^{2-}$ with $\mathrm{H}_{2} \mathrm{~S}$. (a) Time resolved UV-VIS spectra of the interaction of $100 \mu \mathrm{mol} \mathrm{L}{ }^{-1}$ cPTIO with $100 \mu \mathrm{M}$ $\mathrm{SeO}_{3}{ }^{2-}$ (3 times repeated every $30 \mathrm{~s}$, black) and subsequent addition of $100 \mu \mathrm{mol} \mathrm{L}{ }^{-1} \mathrm{H}_{2} \mathrm{~S}$. Spectra were collected every $30 \mathrm{~s}$ for $15 \mathrm{~min}$; the first spectrum, indicated by the solid red line, was measured $15 \mathrm{~s}$ after addition of $\mathrm{H}_{2} \mathrm{~S}$. Top inset: kinetics of changes in absorbance at $560 \mathrm{~nm}$ after addition of $100 \mu \mathrm{mol} \mathrm{L}^{-1} \mathrm{H}_{2} \mathrm{~S}$ into ${ }^{\mathrm{cPTIO}} / \mathrm{SeO}_{3}{ }^{2-}\left(100 / 100 \mathrm{in} \mu \mathrm{mol} \mathrm{L}{ }^{-1}\right)$ solution at time $0 \mathrm{~s}$. Bottom inset: details of the time resolved spectra of the ${ }^{\mathrm{cPTIO}} / \mathrm{SeO}_{3}{ }^{2-}\left(100 / 100 \mathrm{in} \mu \mathrm{mol} \mathrm{L}{ }^{-1}\right)$ interaction before (black) and after addition of $\mathrm{H}_{2} \mathrm{~S}\left(100 \mu \mathrm{mol} \mathrm{L}{ }^{-1}\right.$, the first spectrum is indicated by the solid red line, which is followed each $30 \mathrm{~s}$ by: long dash red, medium dash red, short dash red, dotted red, solid blue line, long dash blue, medium dash blue, etc.). (b, c, d, e) $\mathrm{H}_{2} \mathrm{~S}\left(100 \mu \mathrm{mol} \mathrm{L}^{-1}\right)$ was added to $100 \mu \mathrm{mol} \mathrm{L}{ }^{-1}$ solution of cPTIO containing different concentrations of $\mathrm{SeO}_{3}{ }^{2-}\left(0-400 \mu \mathrm{mol} \mathrm{L}{ }^{-1}\right.$, see legend). The kinetics of the reduction of $100 \mu \mathrm{mol} \mathrm{L}{ }^{-1}{ }_{\mathrm{cPTIO}}$ before and after addition of $100 \mu \mathrm{mol} \mathrm{L}{ }^{-1} \mathrm{H}_{2} \mathrm{~S}$ (marked by arrow) was monitored as a decrease of the absorbance at $358 \mathrm{~nm}$ minus the absorbance at $420 \mathrm{~nm}$ (b, d) and also as a decrease of the absorbance at $560 \mathrm{~nm}(\mathrm{c}, \mathrm{e})$. 


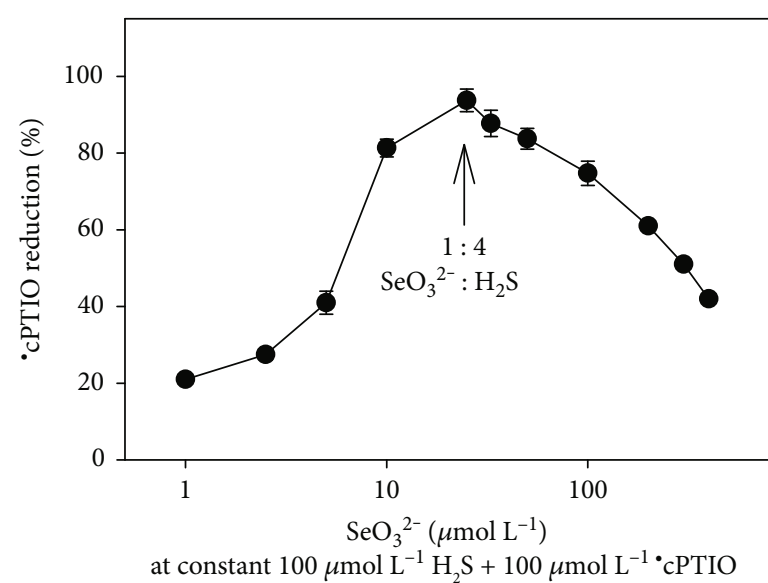

(a)

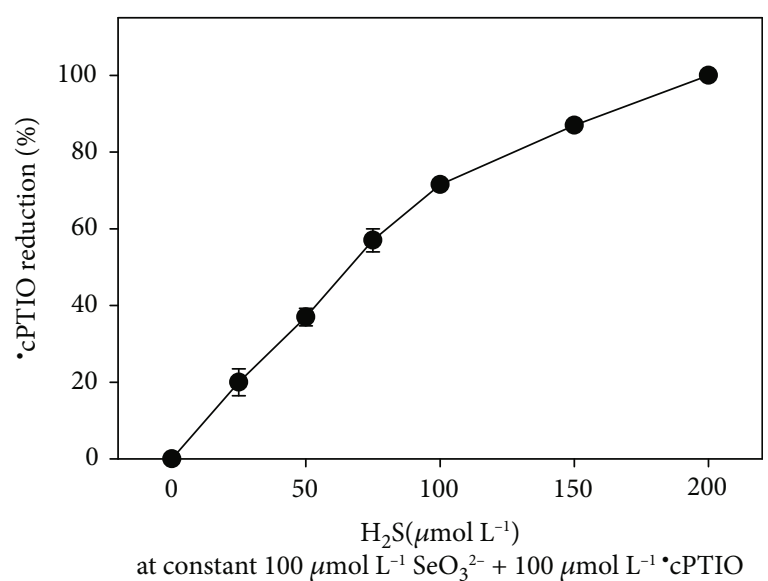

(b)

FIGURE 2: Effect of the $\mathrm{SeO}_{3}{ }^{2-}$ and $\mathrm{H}_{2} \mathrm{~S}$ concentration on the reduction of ${ }^{\prime} \mathrm{CPTIO}$. (a) Effect of the $\mathrm{SeO}_{3}{ }^{2-}$ concentration (1-400 $\mu$ mol L $\mathrm{L}^{-1}$ ) on the reduction of ${ }^{\prime} \mathrm{CPTIO}\left(100 \mu \mathrm{mol} \mathrm{L}^{-1}\right)$ in the presence of $\mathrm{H}_{2} \mathrm{~S}\left(100 \mu \mathrm{mol} \mathrm{L}^{-1}\right)$. Arrow indicates the $1: 4 \mathrm{molar} \mathrm{ratio} \mathrm{of} \mathrm{SeO}_{3}{ }^{2-}: \mathrm{H}_{2} \mathrm{~S}$. (b) Effect of the $\mathrm{H}_{2} \mathrm{~S}$ concentration $\left(0-200 \mu \mathrm{mol} \mathrm{L}^{-1}\right)$ on the reduction of ${ }^{\mathrm{cPTIO}}\left(100 \mu \mathrm{mol} \mathrm{L}^{-1}\right)$ in the presence of $\mathrm{SeO}_{3}{ }^{2-}\left(100 \mu \mathrm{mol} \mathrm{L}{ }^{-1}\right)$. The reduction of ${ }^{~} \mathrm{CPTIO}$ was evaluated as the decrease of the absorbance at $560 \mathrm{~nm}$ after $2.25 \mathrm{~min}$ of the reaction $\left(\mathrm{pH} 7.4,37^{\circ} \mathrm{C}\right)$. All values represent the means \pm S.E.M., $n=2-4$.

increased further in the presence of $\mathrm{SeO}_{3}{ }^{2-}$ (more than three times at a $50 / 25$ in $\mu \mathrm{mol} \mathrm{L}^{-1} \mathrm{H}_{2} \mathrm{~S} \mathrm{SeO}_{3}{ }^{2-}$ ratio). This indicates that $\mathrm{H}_{2} \mathrm{~S} / \mathrm{SeO}_{3}{ }^{2-}$ products scavenge $\mathrm{O}_{2}{ }^{-}$and/or its derivatives. The effects of $\mathrm{H}_{2} \mathrm{~S} / \mathrm{SeO}_{3}{ }^{2-}$ were less pronounced when $\mathrm{KO}_{2} / \mathrm{DMSO}$ was added $5 \mathrm{~min}$ after addition of $\mathrm{H}_{2} \mathrm{~S}_{\mathrm{SeO}}{ }_{3}{ }^{2-}$, suggesting that the reducing intermediate had already decomposed at this stage (Figure 5, S4). Similar results were obtained when $\mathrm{H}_{2} \mathrm{~S}$ was incubated with $\mathrm{SeCl}_{4}$ (Figure S5). This indicates that the production of highly active species, products of the $\mathrm{H}_{2} \mathrm{~S}_{\mathrm{SeO}}{ }_{3}{ }^{2-}$ interaction, was time-dependent: they appeared within a few seconds after addition of $\mathrm{SeO}_{3}{ }^{2-}$ to the $\mathrm{H}_{2} \mathrm{~S}$ solution and their effects diminished after few minutes of interaction.

From our previous studies of $\mathrm{O}_{2}{ }^{--}$reaction with BMPO [5], we assumed that the EPR spectra of the BMPO adducts were superposed on the $\mathrm{BMPO}-\mathrm{OOH} / \mathrm{OH}$ radicals with minor contribution from the BMPO-C radical. Therefore, we simulated the spectra using hyperfine coupling constants for BMPO$\mathrm{OOH}$, BMPO-OH, and BMPO-C (derived from DMSO) radicals. The means of hyperfine coupling constants used were as follows: BMPO-OOH1 (black) $a_{N}=13.30 \pm 0.03 \mathrm{G}, a_{H}=$ $11.7 \pm 0.1 G$; ВMPO-OOH2 (red) $a_{N}=13.24 \pm 0.03 G, a_{H}=$ $9.4 \pm 0.1 \mathrm{G} ; \mathrm{BMPO}-\mathrm{OH} 1$ (green) $a_{N}=13.7 \pm 0.3 \mathrm{G}, a_{H}=$ $12.3 \pm 0.4 \mathrm{G}$; BMPO-OH2 (yellow) $a_{N}=13.6 \pm 0.2 \mathrm{G}, a_{H}=$ $15.3 \pm 0.1 \mathrm{G}$; and BMPO-C (blue) $a_{N}=15.2 \pm 0.1 \mathrm{G}, a_{H}=$ $21.5 \pm 0.1 \mathrm{G}$. The constants are similar to those reported by Zhao et al. [49]. The simulation revealed that $\mathrm{O}_{2}^{--}$was trapped in the control and in the presence of $\mathrm{SeO}_{3}{ }^{2-}$ (Figures 5(a) and 5(b)), since the EPR spectra of BMPO$\mathrm{OOH}$ were only observed. However, $\mathrm{BMPO}-\mathrm{OH}$ component was present in the samples containing $\mathrm{H}_{2} \mathrm{~S}$ alone or with $\mathrm{SeO}_{3}{ }^{2-}$ (Figures 5(c)-5(h)). The results may indicate that $\mathrm{H}_{2} \mathrm{~S}$ alone or with $\mathrm{SeO}_{3}{ }^{2-}$ decomposed $\mathrm{BMPO}-\mathrm{OOH}$ to BMPO$\mathrm{OH}$ and/or $\mathrm{OH}$ was formed as a result of compound presence. Since the first spectrum was recorded $110 \pm 15 s$ after sample preparation, we cannot exclude a possibility of trapping of other radicals with lifetimes shorter than $110 \mathrm{~s}$.
3.3. $\mathrm{H}_{2} \mathrm{~S} / \mathrm{SeO}_{3}{ }^{2-}$ Cleaves $\mathrm{pDNA}$. It was of interest to know if the products of the $\mathrm{H}_{2} \mathrm{~S} / \mathrm{SeO}_{3}{ }^{2-}$ interaction have biological effects in vitro. Therefore, we investigated the direct effects of $\mathrm{H}_{2} \mathrm{~S}$ and $\mathrm{SeO}_{3}{ }^{2-}$ on the cleavage of pDNA in vitro using the Fenton reaction as a positive benchmark control (Figure 6) [5]. Interestingly, neither $\mathrm{H}_{2} \mathrm{~S}\left(1 \mathrm{mmol} \mathrm{L}^{-1}\right)$ nor $\mathrm{SeO}_{3}{ }^{2-}$ (0-1 $\left.\mathrm{mmol} \mathrm{L}^{-1}\right)$ alone significantly cleaved pDNA. In contrast, $\mathrm{SeO}_{3}{ }^{2-}$ in a concentration-dependent manner caused damage to DNA in the presence of $1 \mathrm{mmolL}^{-1} \mathrm{H}_{2} \mathrm{~S}$ (Figures 6(a1) and 6(a2)). The observed cleavage of DNA caused by $\mathrm{SeO}_{3}{ }^{2-}$ and $\mathrm{H}_{2} \mathrm{~S}$ showed a bell-shaped concentration ratio dependence similar to the one observed in the reduction of the cPTIO radical. We can suggest that the intermediate responsibility of the action can be a selenopolysulfide with a $\mathrm{H}_{2} \mathrm{~S}: \mathrm{SeO}_{3}{ }^{2-}$ ratio of $4: 1$. In the presence of $\mathrm{H}_{2} \mathrm{O}_{2}$, damage to pDNA by $\mathrm{H}_{2} \mathrm{~S}$ occurs also without $\mathrm{SeO}_{3}{ }^{2-}$, since $\mathrm{H}_{2} \mathrm{O}_{2}$ now takes on the role of $\mathrm{SeO}_{3}{ }^{2-}$ as an oxidant, with the simultaneous formation of the $\mathrm{OH}$ radicals (Figures 6(b1) and 6 (b2)). Further evidence for the involvement of radicals may come from the fact that dimethylsulfoxide (DMSO), a known $\mathrm{OH}$ scavenger $[50,51]$ frequently employed as solvent in biology, is able to interfere with the damage to DNA (Figures 6(c1) and 6(c2)).

3.4. $\mathrm{H}_{2} \mathrm{~S}_{\mathrm{SeO}}{ }^{2-}$ Modulates Tension of Isolated Thoracic Aorta. As some of our in vitro assays indicated an antioxidant activity of the $\mathrm{H}_{2} \mathrm{~S} / \mathrm{SeO}_{3}{ }^{2-}$ mixture, and $\mathrm{H}_{2} \mathrm{~S}$ is known to promote relaxation of blood vessels [52], the impact of the $\mathrm{H}_{2} \mathrm{~S} / \mathrm{SeO}_{3}{ }^{2-}$ mixture on the isolated thoracic aorta was examined. The thoracic aorta was precontracted by noradrenaline (NA) $\left(1 \mu \mathrm{mol} \mathrm{L}^{-1}\right)$. After a stabile plateau of the contraction was reached (Figure $7(\mathrm{a})$ ), $\mathrm{SeO}_{3}{ }^{2-}$ $\left(100 \mu \mathrm{mol} \mathrm{L}^{-1}\right)$ showed only negligible activity, while $\mathrm{Na}_{2} \mathrm{~S}$ $\left(200 \mu \mathrm{mol} \mathrm{L}^{-1}\right)$ significantly relaxed the aortic rings, in agreement with our previous studies [38]. A simultaneous addition of $\mathrm{SeO}_{3}{ }^{2-}\left(100 \mu \mathrm{mol} \mathrm{L}^{-1}\right)$ and $\mathrm{H}_{2} \mathrm{~S}\left(200 \mu \mathrm{mol} \mathrm{L}^{-1}\right)$ resulted once more in a biphasic activity profile, where a minor 


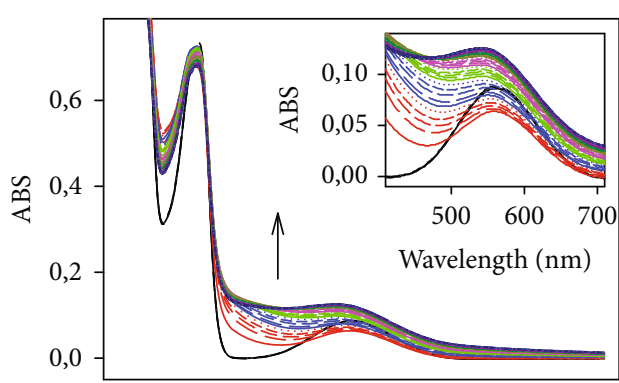

(a)

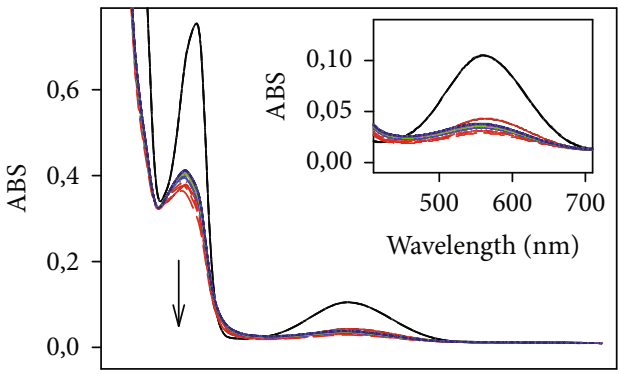

(c)

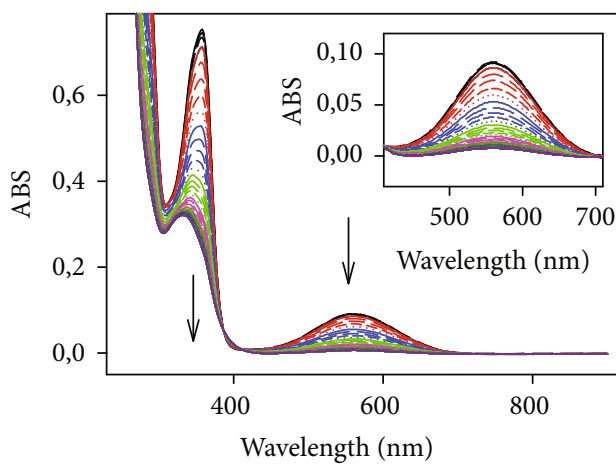

(e)

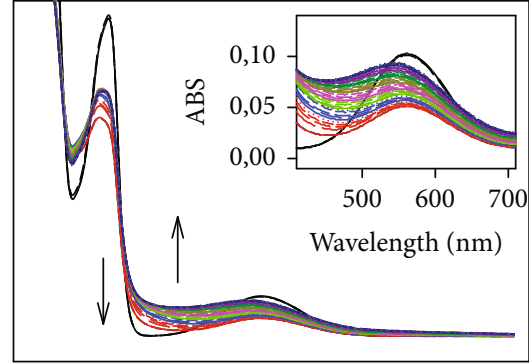

(b)

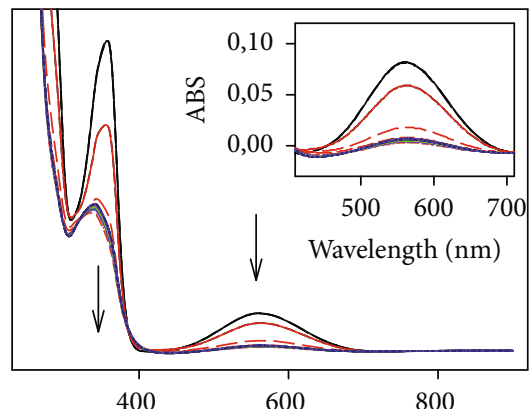

(d)

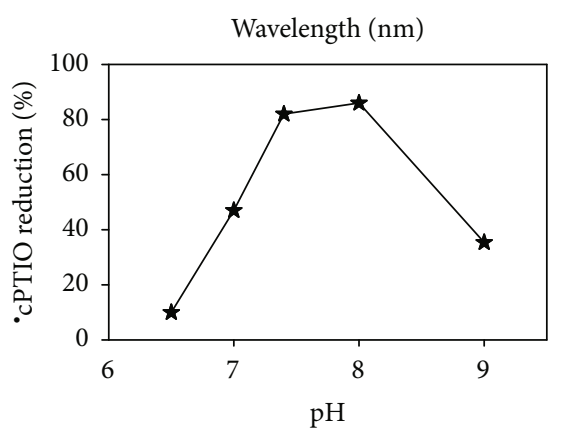

(f)

FIGURE 3: Effect of $\mathrm{pH}$ on the reduction of ' $\mathrm{CPTIO}$ in the presence of $\mathrm{SeO}_{3}{ }^{2-}$ induced by $\mathrm{H}_{2} \mathrm{~S}$. Time resolved UV-VIS spectra of the interaction of $\mathrm{H}_{2} \mathrm{~S}\left(100 \mu \mathrm{mol} \mathrm{L}{ }^{-1}\right.$ final) with ${ }^{\mathrm{cPTIO}} / \mathrm{SeO}_{3}{ }^{2-}$ (100/50 in $\mu \mathrm{mol} \mathrm{L}{ }^{-1}$ final) at $\mathrm{pH} 6.5$ (a), 7.0 (b), 7.4 (c), 8.0 (d), and 9.0 (e). The first spectrum was recorded $15 \mathrm{~s}$ after $\mathrm{H}_{2} \mathrm{~S}$ addition (solid red line) followed each $30 \mathrm{~s}$ by: long dash red, medium dash red, short dash red, dotted red, solid blue line, long dash blue, medium dash blue, etc. Samples were measured every $30 \mathrm{~s}$ for $20 \mathrm{~min}$. The black line represents the spectrum of ${ }^{c} \mathrm{CPTIO} / \mathrm{SeO}_{3}{ }^{2-}$ before the $\mathrm{H}_{2} \mathrm{~S}$ addition. (f) Dependence of ${ }^{\mathrm{c} P T I O}\left(100 \mu \mathrm{mol} \mathrm{L}{ }^{-1}\right)$ reduction by $\left.\mathrm{H}_{2} \mathrm{~S}_{/ \mathrm{SeO}_{3}{ }^{2-}(100 / 50 \mathrm{in} \mu \mathrm{mol} \mathrm{L}}{ }^{-1}\right)$ on $\mathrm{pH}$. Data were taken from the spectra shown in (a), (b), (c), (d), and (e) as a minimum of $A_{560}$ in the range of 0-4 min. The buffers consisted of $100 \mathrm{mmol} \mathrm{L}^{-1}$ sodium phosphate, $100 \mu \mathrm{M}$ DTPA, $37^{\circ} \mathrm{C}$, and $\mathrm{pH}$ values were adjusted to desired $\mathrm{pH}$.

relaxation was noticed first, followed by a pronounced contraction (Figure 7). It is supposed that the contraction effect may result also from the antioxidant properties of the mixture, similarly as it has been reported for ascorbate [53].

3.5. $\mathrm{H}_{2} \mathrm{~S} / \mathrm{SeO}_{3}{ }^{2-}$ Modulates Rat Systolic and Pulse Blood Pressure. Since the products of the $\mathrm{H}_{2} \mathrm{~S} / \mathrm{SeO}_{3}{ }^{2-}$ interaction modulated the tension of the thoracic aorta, we subsequently studied whether the products influence blood pressure (BP). Intravenous (i.v.) administration of $5 \mu \mathrm{mol} \mathrm{kg}^{-1} \mathrm{SeO}_{3}{ }^{2-}$ had only minor effects on BP (Figure $8(\mathrm{~g})$ ). The administration of $10 \mu \mathrm{mol} \mathrm{kg}^{-1}$ of $\mathrm{Na}_{2} \mathrm{~S}$ transiently decreased and increased BP (Figures $8(\mathrm{a})$ and $8(\mathrm{~g})$ ), as observed in our previous study [54]. The stock solution of the $\mathrm{H}_{2} \mathrm{~S}_{/} \mathrm{SeO}_{3}{ }^{2-}$ mixture
(20/10 in $\left.\mathrm{mmol} \mathrm{L}^{-1}\right)$ prepared in $0.9 \% \mathrm{NaCl}$ was colorless and had $\mathrm{pH} \sim 11$. However, when the mixture was prepared in solution with $\mathrm{pH} 7.4$, it had orange color with an absorption maximum at $570 \mathrm{~nm}$ (Figure S6), indicating formation of the sulfur-selenium complexes [40]. The i.v. administration of the mixture $\mathrm{H}_{2} \mathrm{~S}_{/} \mathrm{SeO}_{3}{ }^{2-}\left(10 / 5 \mu \mathrm{mol} \mathrm{kg}{ }^{-1}\right.$, $\mathrm{pH} \sim 7.4$ ), in comparison to $\mathrm{H}_{2} \mathrm{~S}$ alone, inhibited both $\mathrm{BP}$ decrease and increase (Figures $8(\mathrm{~b})$ and $8(\mathrm{~g})$ ). The effects of the mixture were less pronounced at $\mathrm{pH} \sim 11$, being the effects at this $\mathrm{pH}$ similar to those observed for $\mathrm{H}_{2} \mathrm{~S}$ alone (Figures $8(\mathrm{c})$ and $8(\mathrm{~g})$ ).

The studied compounds influenced pulse $\mathrm{BP}$, as an important parameter of cardiovascular system reflecting arterial stiffness $[55,56]$. The administration of $5 \mu \mathrm{mol} \mathrm{kg}^{-1}$ 

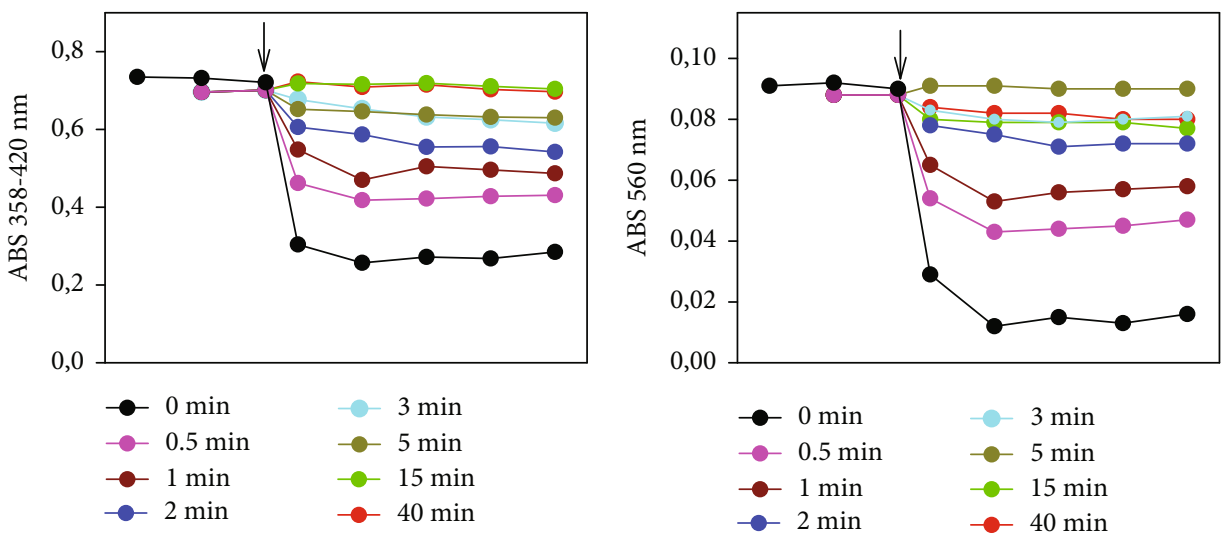

(a)

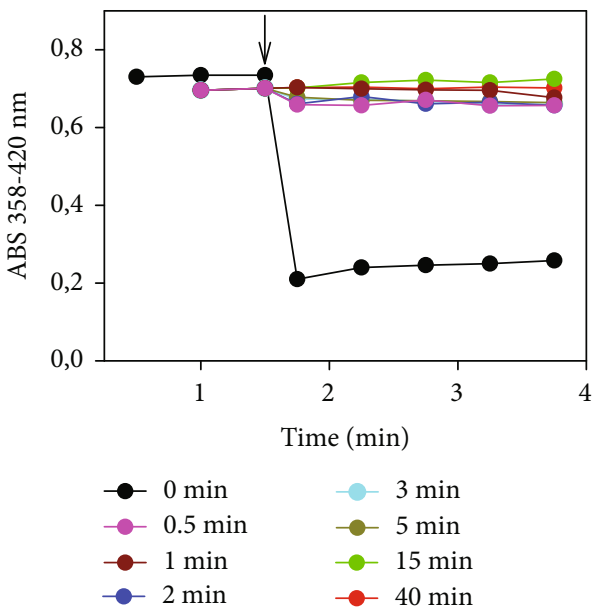

(b)

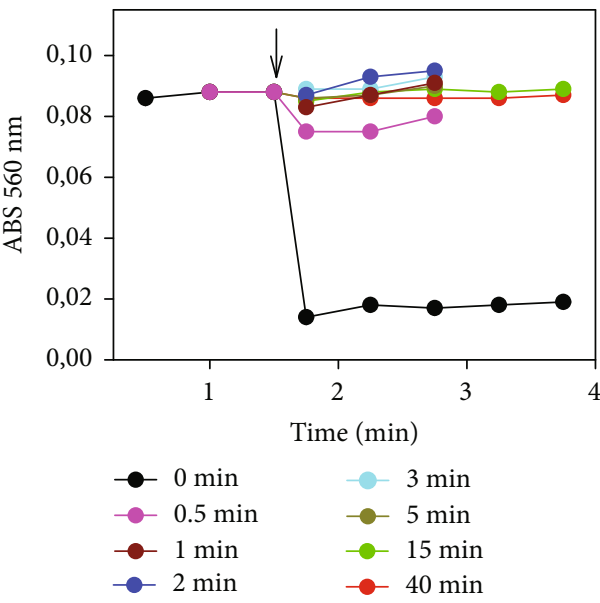

(c)

(d)

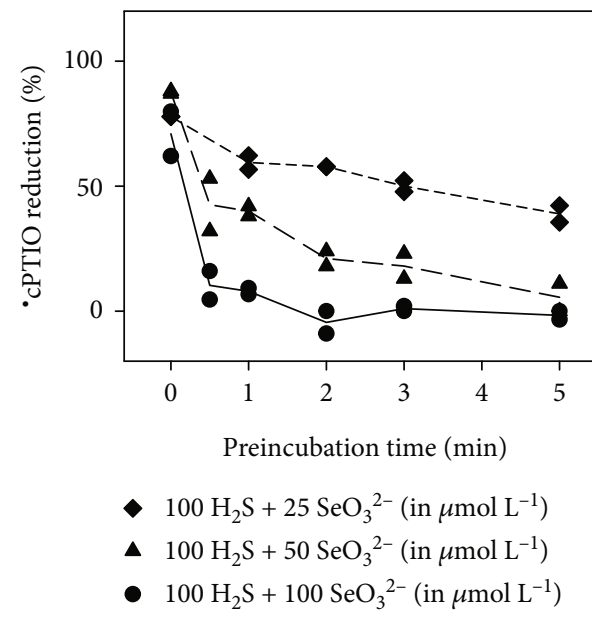

(e)

FIgURE 4: Influence of the preincubation time of the $\mathrm{H}_{2} \mathrm{~S} / \mathrm{SeO}_{3}{ }^{2-}$ mixture on the time-dependent reduction of cPTIO. The reduction of cPTIO $\left(100 \mu \mathrm{mol} \mathrm{L}^{-1}\right)$ once added into the preincubated $\mathrm{H}_{2} \mathrm{~S}_{3} \mathrm{SeO}_{3}{ }^{2-}$ mixture $\left(100 / 50\right.$ in $\left.\mu \mathrm{mol} \mathrm{L}^{-1},(\mathrm{a}, \mathrm{b}) ; 100 / 100 \mathrm{in} \mu \mathrm{mol} \mathrm{L}{ }^{-1}(\mathrm{c}, \mathrm{d})\right)$ was evaluated as the decrease of absorbance at $358 \mathrm{~nm}$ minus $420 \mathrm{~nm}(\mathrm{a}, \mathrm{c})$ and the decrease of absorbance at $560 \mathrm{~nm}$ (b, d), respectively. The preincubation time of the $\mathrm{H}_{2} \mathrm{~S}_{2} \mathrm{SeO}_{3}{ }^{2-}$ mixture was 0-40 min (see legend). (e) Impact of the preincubation time of the $\mathrm{H}_{2} \mathrm{~S} / \mathrm{SeO}{ }_{3}{ }^{2-}$ mixture on the reduction of 'cPTIO. "cPTIO $\left(100 \mu \mathrm{M}\right.$ ) was added into preincubated $\mathrm{H}_{2} \mathrm{~S}_{2} \mathrm{SeO}_{3}{ }^{2-}$ (in $\mu$ mol L ${ }^{-1}, 100 / 100$, circles; $100 / 50$, triangles; $100 / 25$, diamonds) at $\mathrm{pH} 7.4,37^{\circ} \mathrm{C}$. Data represent the reduction of ${ }^{\circ} \mathrm{cPTIO}$ in $1^{\text {st }}$ minute after addition of ${ }^{\circ} \mathrm{cPTIO}$. 


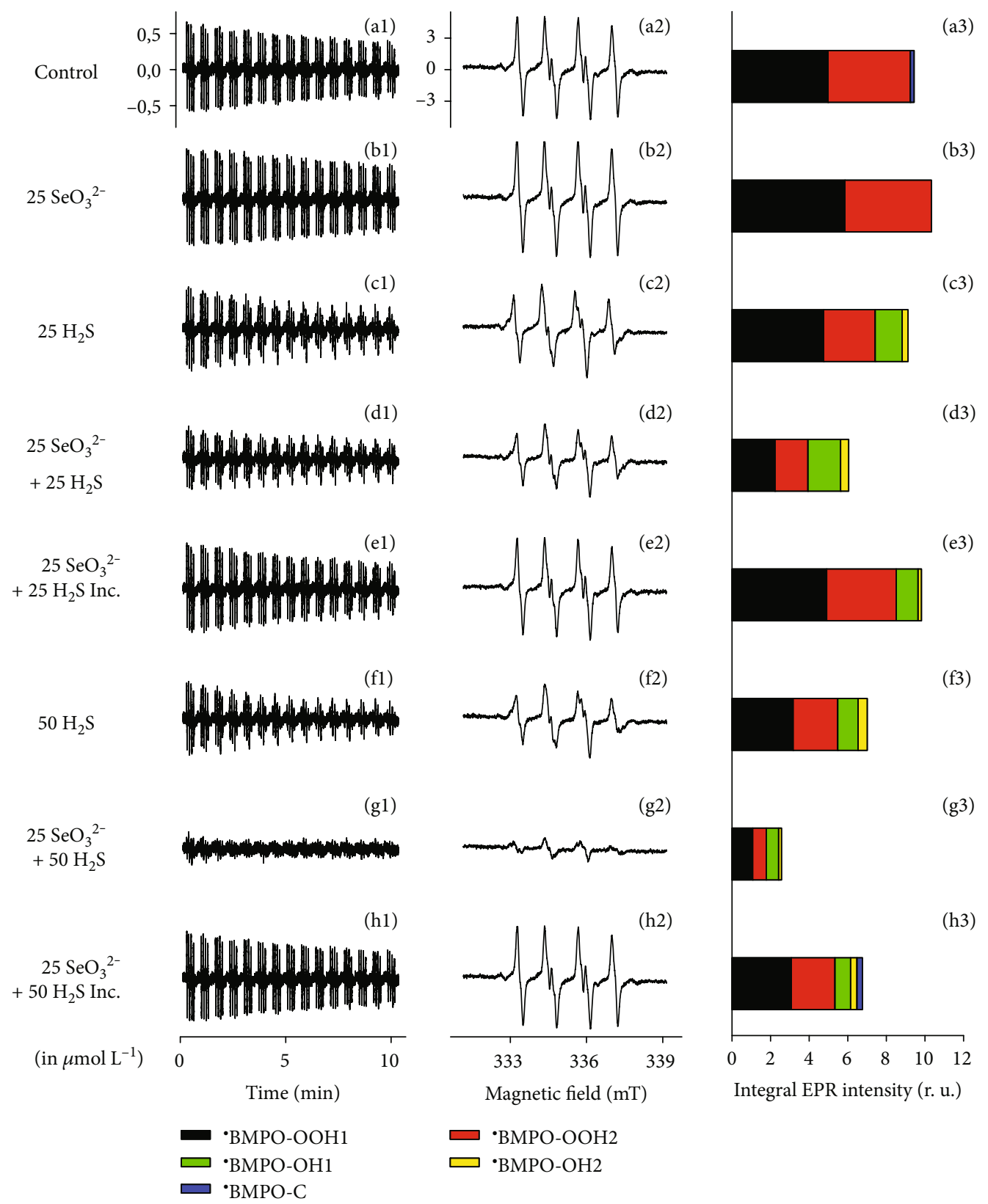

FIgURE 5: EPR spectra of BMPO in the presence of $\mathrm{O}_{2}{ }^{-}$are modulated by $\mathrm{H}_{2} \mathrm{~S}^{-} \mathrm{SeO}_{3}{ }^{2-}$. Representative EPR spectra of the BMPO adducts were monitored in $10 \% v / v$ saturated $\mathrm{KO}_{2} / \mathrm{DMSO}$ solution in $50 \mathrm{mmol} \mathrm{L}^{-1}$ sodium phosphate buffer, $0.1 \mathrm{mmol} \mathrm{L}^{-1} \mathrm{DTPA}$, $\mathrm{pH}_{7.4}, 37^{\circ} \mathrm{C}$ in the presence of the various investigated chalcogen species and $20 \mathrm{mmol} \mathrm{L}^{-1}$ BMPO. Sets of individual EPR spectra of the BMPO adducts monitored upon 15 sequential scans, each $42 \mathrm{~s}$ (a1-h1), starting acquisition $2 \mathrm{~min}$ after sample preparation in: control $10 \%$ v/ $v$ $\mathrm{KO}_{2} /$ DMSO in the buffer (a1), the $\mathrm{KO}_{2} / \mathrm{DMSO}$ in the presence of $25 \mu \mathrm{mol} \mathrm{L}^{-1} \mathrm{SeO}_{3}{ }^{2-}$ (b1), $25 \mu \mathrm{mol} \mathrm{L}^{-1} \mathrm{H}_{2} \mathrm{~S}$ (c1), mixture of $25 / 25$ in $\mu \mathrm{mol} \mathrm{L}^{-1} \mathrm{H}_{2} \mathrm{~S}_{2} \mathrm{SeO}_{3}{ }^{2-}(\mathrm{d} 1), 25 / 25$ in $\mu \mathrm{mol} \mathrm{L}^{-1} \mathrm{H}_{2} \mathrm{~S}_{2} \mathrm{SeO}_{3}{ }^{2-}$ preincubated $5 \mathrm{~min}$ before $\mathrm{KO}_{2} / \mathrm{DMSO}$ stock solution addition (e1), $50 \mu \mathrm{mol} \mathrm{L}^{-1} \mathrm{H}_{2} \mathrm{~S}$ (f1), mixture of $50 / 25$ in $\mu \mathrm{mol} \mathrm{L}{ }^{-1} \mathrm{H}_{2} \mathrm{~S} / \mathrm{SeO}_{3}{ }^{2-}(\mathrm{g} 1)$, and $50 / 25$ in $\mu \mathrm{mol} \mathrm{L}^{-1} \mathrm{H}_{2} \mathrm{~S} / \mathrm{SeO}_{3}{ }^{2-}$ preincubated $5 \mathrm{~min}$ before addition of $\mathrm{KO}_{2} / \mathrm{DMSO}$ stock solution (h1). The spectra (a2-h2) show details of the accumulated first ten spectra of the (a1-h1) sets. The intensities of the time-dependent EPR spectra (a1-h1) and detailed spectra (a2-h2) are comparable; they were measured under identical EPR settings. EPR modulation amplitude $0.15 \mathrm{mT}$. (a3-h3) Comparison of the integral intensity of individual components of simulated $\mathrm{BMPO}+\mathrm{O}_{2}^{-}$without (control) and with chalcogen species shown in (a1-h1). The first five EPR spectra were accumulated and used for simulation. The data represent the means of $n=2$; standard error was $\leq 10 \%$ of the mean value. Simulated relative intensities of the two conformers of the radicals: BMPO-OOH1 (black), BMPO-OOH2 (red), BMPO-OH1 (green), BMPO-OH2 (yellow), and BMPO-C (blue). 
(a1)

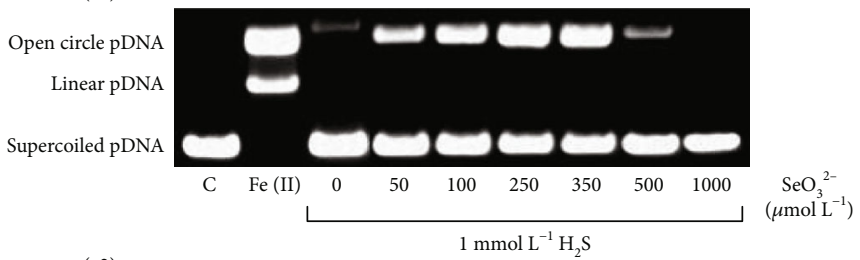

(a2)

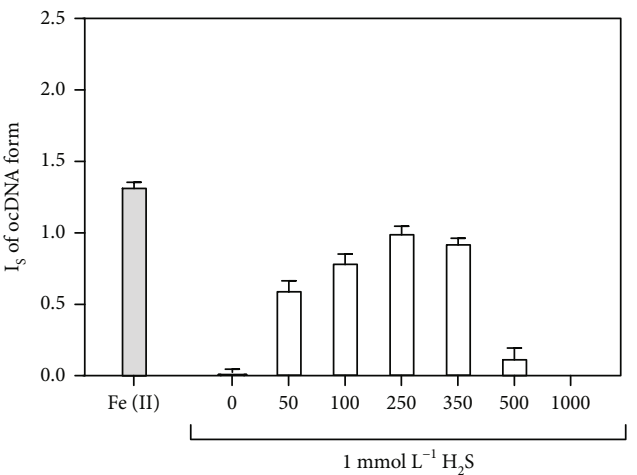

(a) (b1)

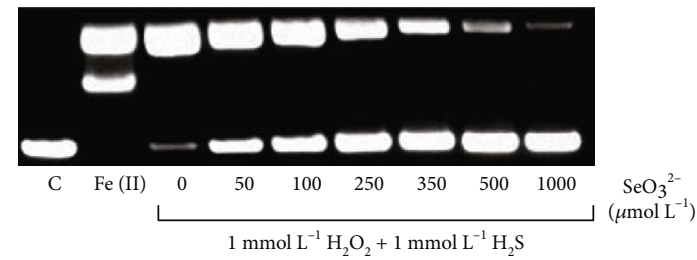

(b2)

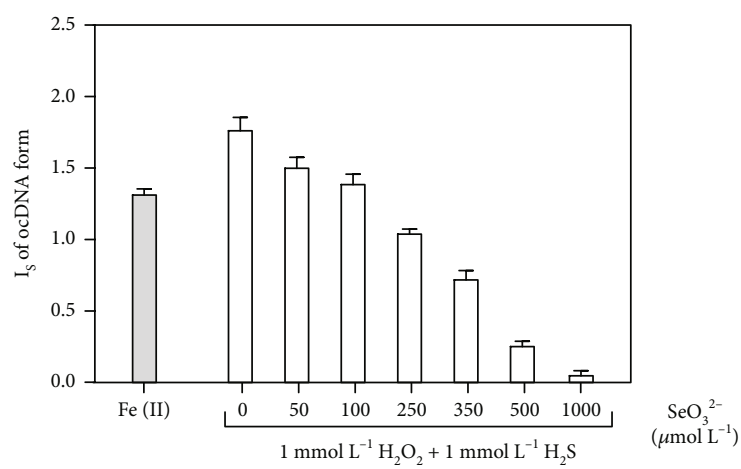

(b)

(c1)

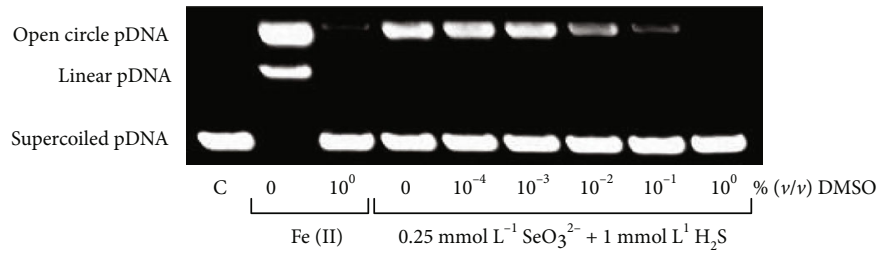

$(\mathrm{c} 2)$

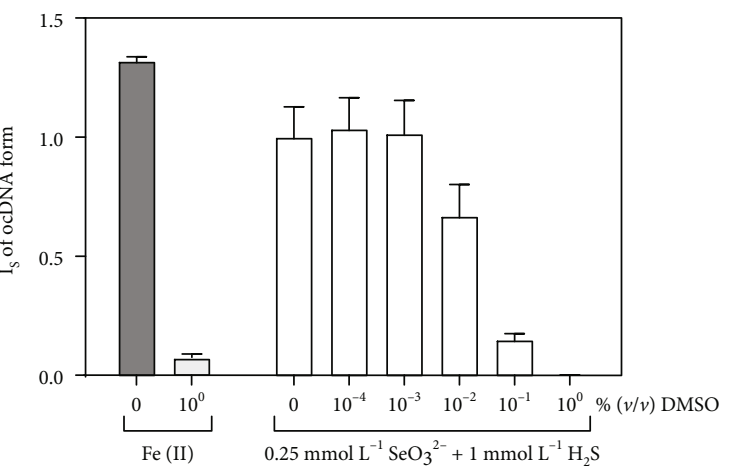

(c)

Figure 6: The influence of $\mathrm{H}_{2} \mathrm{~S}_{/ \mathrm{SeO}_{3}}{ }^{2-}$ on pDNA cleavage in the absence and presence of $\mathrm{H}_{2} \mathrm{O}_{2}$ and DMSO. Representative gels (a1, b1) and column graphs $(\mathrm{a} 2, \mathrm{~b} 2)$ indicating the effects of increasing concentrations of $\mathrm{SeO}_{3}{ }^{2-}\left(0-1 \mathrm{mmol} \mathrm{L}^{-1}\right)$ on pDNA cleavage in the presence of $1 \mathrm{mmol} \mathrm{L} \mathrm{H}_{2} \mathrm{~S}$, without (a1, a2) and with $1 \mathrm{mmol} \mathrm{L}^{-1} \mathrm{H}_{2} \mathrm{O}_{2}$ (b1, b2). The band at the bottom corresponds to the circular supercoiled form of pDNA, and the less intense band appearing above, in the case of $\mathrm{Fe}^{2+}-\mathrm{H}_{2} \mathrm{O}_{2}$, represents the linear form of pDNA. The top band corresponds to the nicked circular form of pDNA. The effects of $150 \mu \mathrm{mol} \mathrm{L}-1 \mathrm{FeCl}_{2}+1 \mathrm{mmol} \mathrm{L}^{-1} \mathrm{H}_{2} \mathrm{O}_{2}$ (full column) are shown for comparison. Values are the means \pm S.E.M., $n=3$. Representative gels (c1) and column graph (c2) showing the effects of increasing concentrations of DMSO on $\mathrm{H}_{2} \mathrm{~S}_{/ \mathrm{SeO}_{3}}{ }^{2-}\left(0.25 / 1 \mathrm{in} \mathrm{mmol} \mathrm{L}{ }^{-1}\right)$-induced pDNA cleavage. DMSO concentrations: $1 \times 10^{-4} \%(v / v) \mathrm{DMSO}=$ $14.1 \mu \mathrm{mol} \mathrm{L}{ }^{-1}$ DMSO; $1 \times 10^{-3} \%=141 \mu \mathrm{mol} \mathrm{L}^{-1} ; 1 \times 10^{-2} \%=1.41 \mathrm{mmol} \mathrm{L}^{-1} ; 1 \times 10^{-1} \%=14.1 \mathrm{mmol} \mathrm{L}^{-1} ; 1 \times 10^{0} \%=141 \mathrm{mmol} \mathrm{L}^{-1}$. Values represent means \pm S.E.M., $n=4$.

$\mathrm{SeO}_{3}{ }^{2-}$ intravenously had minor effects on pulse $\mathrm{BP}$ (Figure $8(\mathrm{~h})$ ). The administration of $10 \mu \mathrm{mol} \mathrm{kg}^{-1}$ of $\mathrm{Na}_{2} \mathrm{~S}$ transiently increased and later decreased pulse BP (Figures $8(\mathrm{~d})$ and $8(\mathrm{~h})$ ) [54]. The i.v. administration of the mixture $\mathrm{H}_{2} \mathrm{~S} \mathrm{SeO}_{3}{ }^{2-}$ (10/5 in $\left.\mu \mathrm{mol} \mathrm{kg}^{-1}, \mathrm{pH} \sim 7.4\right)$, with comparison to $\mathrm{H}_{2} \mathrm{~S}$ alone, eliminated pulse $\mathrm{BP}$ increase, but did not affect pulse BP decrease (Figures $8(\mathrm{e})$ and $8(\mathrm{~h})$ ). The effects of the mixture were less pronounced at $\mathrm{pH} \sim 11$ and were similar to those observed for $\mathrm{H}_{2} \mathrm{~S}$ alone (Figures 8(f) and 8(h)). The inefficiency of the 


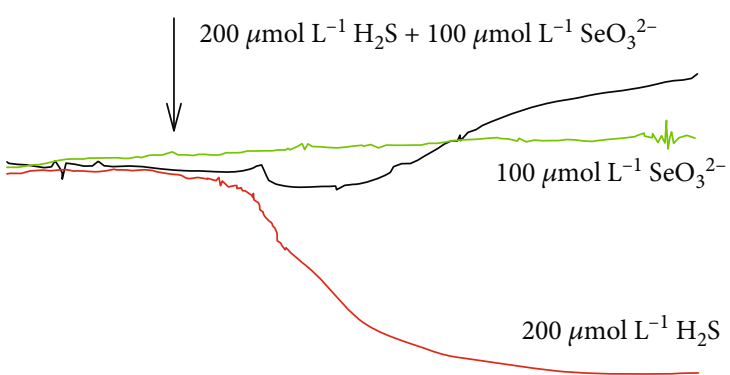

(a)

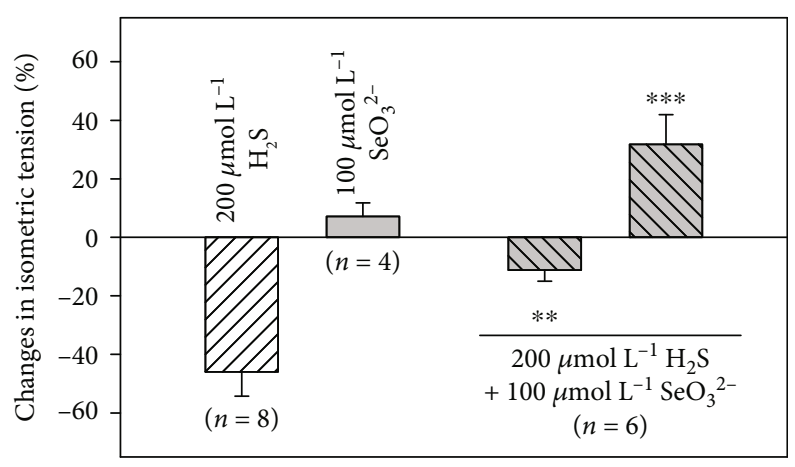

(b)

Figure 7: Time-dependent tonus of isolated thoracic aorta. The original records of changes in NA $\left(1 \mu\right.$ mol L $\left.\mathrm{L}^{-1}\right)$-increased arterial tone of isolated rat thoracic aorta after addition of $\mathrm{SeO}_{3}{ }^{2-}\left(100 \mu \mathrm{mol} \mathrm{L}{ }^{-1}\right), \mathrm{H}_{2} \mathrm{~S}\left(200 \mu \mathrm{mol} \mathrm{L}{ }^{-1}\right)$, and $\mathrm{H}_{2} \mathrm{~S}_{2} \mathrm{SeO}_{3}{ }^{2-}\left(200 / 100\right.$ in $\left.\mu \mathrm{mol} \mathrm{L}{ }^{-1}\right) \mathrm{mixture}$. The arrow indicates the compound application (a). The effects of $\mathrm{SeO}_{3}{ }^{2-}, \mathrm{H}_{2} \mathrm{~S}$, and $\mathrm{H}_{2} \mathrm{~S}_{/} \mathrm{SeO}_{3}{ }^{2-}$ on NA $\left(1 \mu\right.$ mol L $\left.{ }^{-1}\right)$-precontracted rings of rat thoracic aorta. The rings were exposed to bolus dose of $\mathrm{H}_{2} \mathrm{~S}\left(200 \mu \mathrm{mol} \mathrm{L}^{-1}\right.$, relaxation), $\mathrm{SeO}_{3}^{2-}\left(100 \mu \mathrm{mol} \mathrm{L}^{-1}\right.$, nonsignificant contraction), and that of the mixture $\mathrm{H}_{2} \mathrm{~S}_{/} \mathrm{SeO}_{3}{ }^{2-}\left(100 \mu \mathrm{mol} \mathrm{L}^{-1}\right.$ of $\mathrm{SeO}_{3}{ }^{2-}$ immediately followed by $\left.200 \mu \mathrm{mol} \mathrm{L}^{-1} \mathrm{H}_{2} \mathrm{~S}\right)$. The SeO ${ }_{3}^{2-} / \mathrm{H}_{2} \mathrm{~S}$ mixture had a biphasic activity; firstly, it significantly relaxed the aorta, which was followed by significant contraction (b). Asterisks mark the statistical significance of $\mathrm{H}_{2} \mathrm{~S} \mathrm{SeO}_{3}{ }^{2-}$ mixture vs. $\mathrm{H}_{2} \mathrm{~S}\left({ }^{* *} \mathrm{P}<0.01,{ }^{* * *} \mathrm{P}<0.001\right)$.

$\mathrm{H}_{2} \mathrm{~S} / \mathrm{SeO}_{3}{ }^{2-}$ products at $\mathrm{pH} \sim 11$ may be connected with the minor effect of the mixture on the $\mathrm{cPTIO}$ radical reduction at high $\mathrm{pH}$ (Figures $3(\mathrm{e})$ and $3(\mathrm{f})$ ). This may imply that the reduction properties of the mixture could be responsible for their effects on systolic and pulse BP. The results confirm that the products of the $\mathrm{H}_{2} \mathrm{~S} / \mathrm{SeO}_{3}{ }^{2-}$ interaction depend on $\mathrm{pH}$ and influence differently the cardiovascular system. In conclusion, the reactivity and biological activity of the $\mathrm{H}_{2} \mathrm{~S} / \mathrm{SeO}_{3}{ }^{2-}$ interaction products prepared at $\mathrm{pH} 7.4$ differ from those of $\mathrm{Na}_{2} \mathrm{~S}$ alone.

\section{Discussion and Conclusions}

Overall, our studies demonstrate that the two suspected and commonly used "antioxidants," $\mathrm{H}_{2} \mathrm{~S}$ and $\mathrm{SeO}_{3}{ }^{2-}$, are not necessarily typical reducing agents, such as ascorbic acid or tocopherol, when employed on their own. Interestingly, these two chalcogen agents, when added together, rapidly activate each other and form a cascade of considerably more reactive, often reducing species, supposing the involvement of inorganic $\mathrm{HSSeSH}$ and polysulfides $\mathrm{S}_{x}{ }^{2-}$, which may account for some of the observed biological actions. The nature of some of these intermediate reactive sulfur and/or selenium species was suggested in a recently published review [40].

The fast and efficient reduction of the cPTIO radical by $\mathrm{H}_{2} \mathrm{~S}_{/} \mathrm{SeO}_{3}{ }^{2-}$ products (Figures 1 and 4 ) supports the notion that the initial intermediate(s) formed by the reaction of $\mathrm{H}_{2} \mathrm{~S}$ with $\mathrm{SeO}_{3}{ }^{2-}$ are responsible for this kind of action. The bell shape and the maximum radical scavenging activity of $\mathrm{H}_{2} \mathrm{~S}: \mathrm{SeO}_{3}{ }^{2-}$ at a ratio of $\sim 4: 1$ (Figure 2) may indicate the suggested formation of (HSS) ${ }_{2} \mathrm{Se}$ [40]. The kinetics and efficiency of the $\mathrm{H}_{2} \mathrm{~S} / \mathrm{SeO}_{3}{ }^{2-}$ products to reduce ${ }^{2} \mathrm{PTIO}$ (Figure 3) point out to complex $\mathrm{pH}$-dependent chemical and radical reactions of the species.

Reactions of $\mathrm{H}_{2} \mathrm{~S}$ or polysulfides with $\mathrm{SeO}_{3}{ }^{2-}$ and/or $\mathrm{SeCl}_{4}$ were reported [40,57-59]. They point towards a rapid conversion of $\mathrm{SeO}_{3}{ }^{2-}$ and $\mathrm{SeCl}_{4}$ to an intermediate, probably $\mathrm{HSSeSH}$, and a subsequent, slower reductive elimination of this intermediate to elemental (mixed) chalcogen particles and disulfides [40]. However, to our knowledge, there is no information about the formation and detection of HSSeSH in cells or its cytoprotective or other biological effect. The first synthesis of H-S-Se-S-H (1.3-dithiatriselane) was reported by Hahn and Klünsch in 1994, but the stability and reactivity in aqueous solution were not investigated. Solid $\mathrm{HSSeSH}$ has a melting point at $-40^{\circ} \mathrm{C}$. It was one component of a mixture of $\mathrm{H}_{2} \mathrm{~S}_{2} \mathrm{Se}_{\mathrm{n}}$, prepared by the interaction of $2 \mathrm{H}_{2} \mathrm{~S}$ with $\mathrm{Se}_{2} \mathrm{Cl}_{2}$ [60].

The EPR data (Figure 5) once more confirm that $\mathrm{SeO}_{3}{ }^{2-}$ on its own is not an antioxidant; it becomes activated by reduction, for instance, by $\mathrm{H}_{2} \mathrm{~S}$, which concurrently is activated by oxidation. The mutual redox activation is fast, and, as in the case of the $\mathrm{cPTIO}$ radical scavenging, the pristine mixture of $\mathrm{H}_{2} \mathrm{~S}$ and $\mathrm{SeO}_{3}{ }^{2-}$ is most active, with a decrease of activity over the time, pointing once more at simple $\mathrm{H}_{2} \mathrm{~S}_{x}$ or $\mathrm{H}_{2} \mathrm{~S}_{x} \mathrm{Se}$, and notably HSSeSH, but not an $\mathrm{S}_{x} \mathrm{Se}_{y}$, as being responsible for this kind of activity.

We found that the products of this described $\mathrm{H}_{2} \mathrm{~S} \mathrm{SeO}_{3}{ }^{2-}$ interaction have several noteworthy biological effects, involving ROS scavenging, modulation of the redox state, reaction with DNA, tensing isolated aorta, and influencing BP and pulse BP (Figures 6-8). These effects obviously need to be investigated further and in considerably more detail and were not present or were less pronounced when $\mathrm{H}_{2} \mathrm{~S}$ or selenite acted alone. The properties of the products of the $\mathrm{H}_{2} \mathrm{~S} / \mathrm{SeO}_{3}{ }^{2-}$ interactions significantly depended on the $\mathrm{H}_{2} \mathrm{~S} \mathrm{SeO}_{3}{ }^{2-}$ molar ratio, $\mathrm{pH}$, and preincubation time. The combination of these variables makes the work with $\mathrm{H}_{2} \mathrm{~S}_{\mathrm{SeO}}{ }^{2-}$ very complicated, and these facts should be taken into account at the time of designing in vitro and in vivo experiments. These properties of the products may explain the previously published beneficial and contrasting toxic Se 


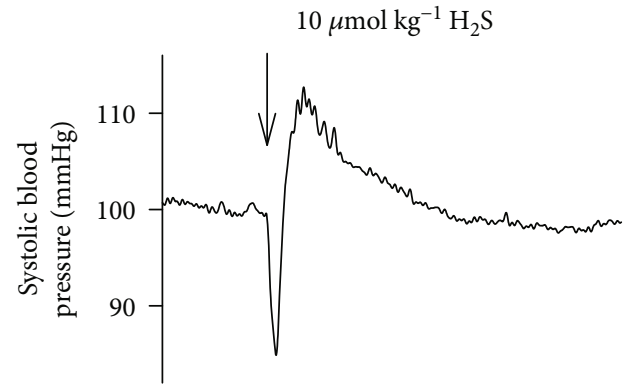

(a)

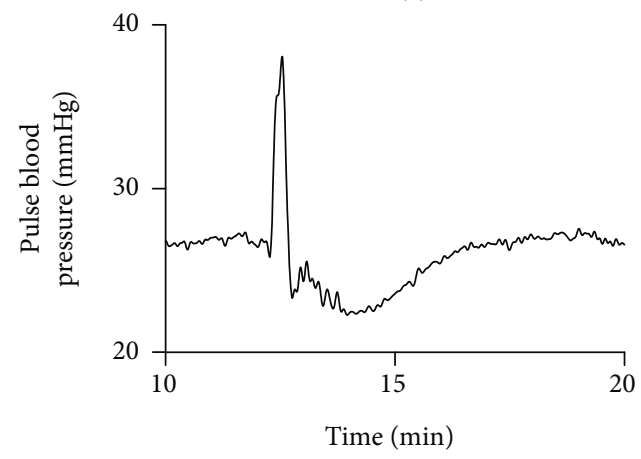

(d)

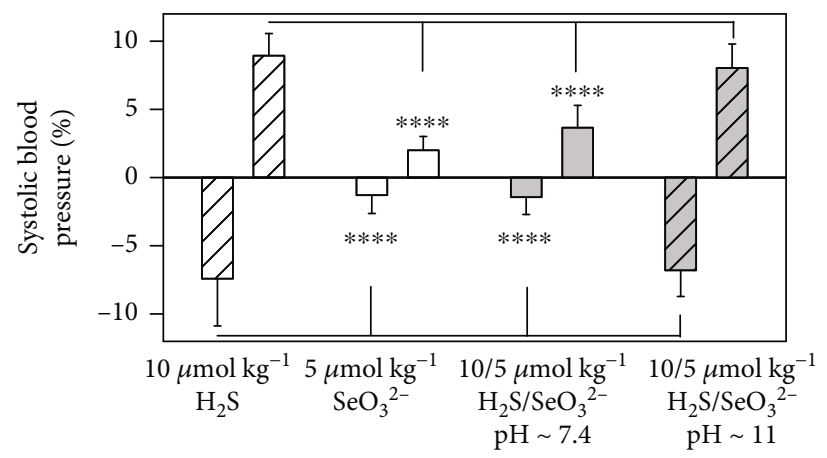

(g)

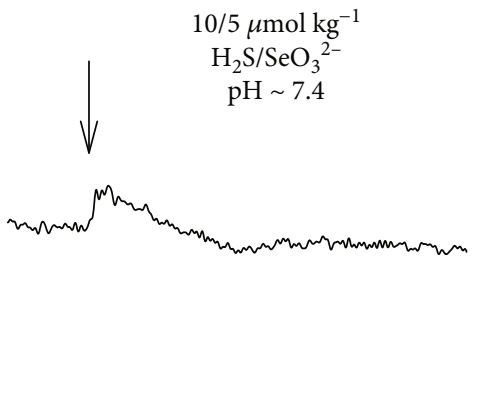

(b)

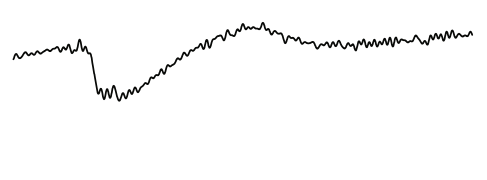

(e)

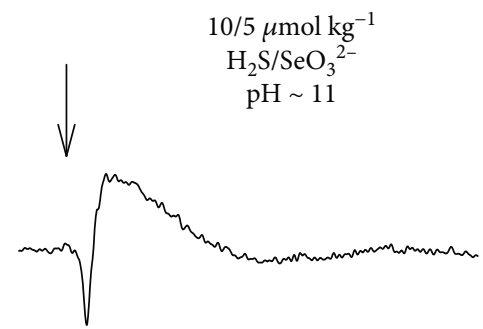

(c)

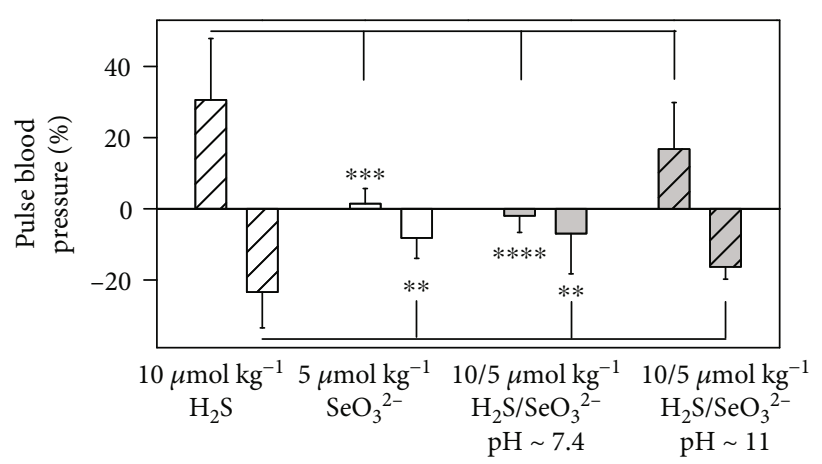

(h)

Figure 8: The time-dependent effects of $\mathrm{SeO}_{3}{ }^{2-}, \mathrm{H}_{2} \mathrm{~S}$, and $\mathrm{H}_{2} \mathrm{~S} / \mathrm{SeO}_{3}{ }^{2-}$ on rat $\mathrm{BP}$ and pulse BP. Representative traces of the time-dependent effect of i.v. bolus administration of $\mathrm{H}_{2} \mathrm{~S}(10 \mu \mathrm{mol} \mathrm{kg}-1$; (a, d) $)$ and its mixture with $5 \mu \mathrm{mol} \mathrm{kg}^{-1} \mathrm{SeO}_{3}{ }^{2-}$ prepared at $\mathrm{pH} \sim 7.4(\mathrm{~b}, \mathrm{e})$ and $\mathrm{pH} \sim 11(\mathrm{c}, \mathrm{f})$ solution on BP $(\mathrm{a}, \mathrm{b}, \mathrm{c})$ and pulse BP $(\mathrm{d}, \mathrm{e}, \mathrm{f})$. Transient changes of rat BP (g) and pulse BP (h) after i.v. bolus administration of $\mathrm{SeO}_{3}{ }^{2-}\left(5 \mu \mathrm{mol} \mathrm{kg}{ }^{-1}\right.$, empty column $), \mathrm{H}_{2} \mathrm{~S}\left(10 \mu \mathrm{mol} \mathrm{kg}{ }^{-1}\right.$, empty coarse column $)$ and their mixture $\left(\mathrm{SeO}_{3}{ }^{2-} / \mathrm{H}_{2} \mathrm{~S}, 5 / 10\right.$ in $\mu \mathrm{mol} \mathrm{kg}{ }^{-1}$ ) prepared at $\mathrm{pH} \sim 7.4$ (grey column) and $\mathrm{pH} \sim 11$ (grey coarse column). Data are presented as means $\pm \mathrm{SD} ; n=5-10$. To test a statistical significance between group differences, we used one-way ANOVA followed by Dunnett's test for multiple comparisons. Hence, we also observed the biphasic effect of $\mathrm{Na}_{2} \mathrm{~S}$ in our previous study [54]; we compared a set of "first part" and "second part" effects of SeO ${ }_{3}^{2-}$, $\mathrm{H}_{2} \mathrm{~S}_{/} \mathrm{SeO}_{3}{ }^{2-}$ at $\mathrm{pH} \sim 7.4$, and $\mathrm{H}_{2} \mathrm{~S}_{/ \mathrm{SeO}_{3}}{ }^{2-}$ at $\mathrm{pH} \sim 11.0$ to the corresponding effect of $\mathrm{Na}_{2} \mathrm{~S}$ on systolic or pulse blood pressure. Only the mixture of $\mathrm{H}_{2} \mathrm{~S}_{\mathrm{SeO}}{ }_{3}{ }^{2-}$ prepared at $\mathrm{pH} \sim 11.0$ was able to generate similar decrease and subsequent increase or vice versa in systolic blood pressure or pulse blood pressure as the $\mathrm{H}_{2} \mathrm{~S}$, respectively. Asterisks mark the statistical significance as follows: ${ }^{* *} P<0.01,{ }^{* * *} P<0.001$, and ${ }^{* * * *} P<0.0001$.

effects, for example, in conditions of oxidative stress and cancer $[12-14,18,20,22,23,30]$.

$\mathrm{H}_{2} \mathrm{~S}$ is endogenously produced in vivo in most, if not in all, cells, and $\mathrm{H}_{2} \mathrm{~S}$ donors are commonly used in biological experiments, and they are considered to be applied in medicine. Our results suggest that in biological experiments with selenite, in its nutrition supplement and clinical use, effects of the $\mathrm{H}_{2} \mathrm{~S}_{\mathrm{SeO}}{ }_{3}{ }^{2-}$ interaction should be considered. While $\mathrm{SeO}_{3}{ }^{2-}$ is used widely as a nutritional supplement already, one may, in the future, wish to spice it up with some reduced sulfur. Natural spices such as garlic and onions contain suitable sulfide releasing agents, such as diallyltrisulfide (DATS) and diallyltetrasulfide (DATTS), which both occur naturally in garlic, or dipropyltrisulfide and dipropyltetrasulfide, both present in onions [61]. Our results imply that application research of suitable $\mathrm{H}_{2} \mathrm{~S}_{2} \mathrm{SeO}_{3}{ }^{2-}$ supplements may lead to the beneficial effects in pathological conditions arising, e.g., from ROS overproduction. 


\author{
Abbreviations \\ ABS: Absorbance \\ BMPO: 5-tert-butoxycarbonyl-5-methyl-1-pyrroline- $N$-oxide \\ BP: $\quad$ Blood pressure \\ cPTIO: 2-(4-Carboxyphenyl)-4,4,5,5-tetramethylimidazo- \\ line-1-oxyl-3-oxide \\ DTPA: Diethylenetriaminepentaacetic acid \\ EPR: $\quad$ Electron paramagnetic resonance \\ $\mathrm{H}_{2} \mathrm{~S}$ : Hydrogen sulfide \\ $\mathrm{H}_{2} \mathrm{O}_{2}$ : Hydrogen peroxide \\ i.p.: Intraperitoneal \\ i.v.: Intravenous \\ NA: $\quad$ Noradrenaline \\ pDNA: Plasmid DNA \\ $\mathrm{SeCl}_{4}$ : $\quad$ Selenium tetrachloride \\ $\mathrm{SeO}_{3}{ }^{2-}$ : Selenite \\ UV/VIS: Ultraviolet-visible.
}

\section{Data Availability}

All findings and conclusions are based on the presented figures in the main text or in the supplementary information. Original source files (UV-VIS spectra, EPR spectra, DNA gels, rat blood pressure records, and aorta relaxation records) can be sent from the corresponding author, Dr. Karol Ondrias, upon request.

\section{Conflicts of Interest}

The authors declare no conflict of interest.

\section{Authors' Contributions}

K.O. and M.C. conceived, initiated, and coordinated the study; K.O., M.C, and V.B. designed research; K.O., M.G., A.M., and A.K. performed UV-VIS experiments and analyzed data; V.B., K.O., M.G., and A.M. performed EPR experiments and analyzed data; M.C. and A.M. performed pDNA cleavage experiments and analyzed data; L.T., A.M, K.O., S.C., A.B., and P.B. performed aorta experiments and analyzed data; L.K., A.M., S.C., A.B., and K.O. performed rat in vivo experiments. K.O. wrote the paper; K.O., M.C., V.B., A.K., and E.A-D contributed to analyze data and manuscript writing. Marian Grman and Anton Misak contributed equally to this work. Miroslav Chovanec and Karol Ondrias shared senior authorship.

\section{Acknowledgments}

This research was funded by the Slovak Research and Development Agency (grant numbers APVV-15-0371 to A.M., M.G., and K.O.; APVV-17-0384 to M.C.; and APVV-150565 to A.M, S.C., A.B., and P.B.), the VEGA Grant Agency of the Slovak Republic (grant numbers 2/0079/19 to M.G.; $1 / 0026 / 18$ to V.B.; $2 / 0053 / 19$ to M.C.; and $2 / 0014 / 17$ to K.O.), and University Science Park for Biomedicine (ITMS 26240220087).

\section{Supplementary Materials}

The supplementary information's file (PDF) contains only additional figures with legends to the main manuscript text. (Supplementary Materials)

\section{References}

[1] R. Wang, "Physiological implications of hydrogen sulfide: a whiff exploration that blossomed," Physiological Reviews, vol. 92, no. 2, pp. 791-896, 2012.

[2] C. Szabo and A. Papapetropoulos, "International union of basic and clinical pharmacology. CII: pharmacological modulation of $\mathrm{H}_{2} \mathrm{~S}$ levels: $\mathrm{H}_{2} \mathrm{~S}$ donors and $\mathrm{H}_{2} \mathrm{~S}$ biosynthesis inhibitors," Pharmacological Reviews, vol. 69, no. 4, pp. 497-564, 2017.

[3] L. Tomasova, P. Konopelski, and M. Ufnal, "Gut bacteria and hydrogen sulfide: the new old players in circulatory system homeostasis," Molecules, vol. 21, no. 11, p. 1558, 2016.

[4] Y.-H. Liu, M. Lu, L.-F. Hu, P. T.-H. Wong, G. D. Webb, and J.S. Bian, "Hydrogen sulfide in the mammalian cardiovascular system," Antioxidants and Redox Signaling, vol. 17, no. 1, pp. 141-185, 2012.

[5] A. Misak, M. Grman, Z. Bacova et al., "Polysulfides and products of $\mathrm{H}_{2} \mathrm{~S}$ /S-nitrosoglutathione in comparison to $\mathrm{H}_{2} \mathrm{~S}$, glutathione and antioxidant Trolox are potent scavengers of superoxide anion radical and produce hydroxyl radical by decomposition of $\mathrm{H}_{2} \mathrm{O}_{2}$," Nitric Oxide, vol. 76, pp. 136-151, 2018.

[6] A. Staško, V. Brezová, M. Zalibera, S. Biskupič, and K. Ondriaš, "Electron transfer: a primary step in the reactions of sodium hydrosulphide, an $\mathrm{H}_{2} \mathrm{~S} / \mathrm{HS}^{-}$donor," Free Radical Research, vol. 43, no. 6, pp. 581-593, 2009.

[7] M. Whiteman, J. S. Armstrong, S. H. Chu et al., "The novel neuromodulator hydrogen sulfide: an endogenous peroxynitrite 'scavenger'?," Journal of Neurochemistry, vol. 90, no. 3, pp. 765-768, 2004.

[8] M. Whiteman, N. S. Cheung, Y.-Z. Zhu et al., "Hydrogen sulphide: a novel inhibitor of hypochlorous acid-mediated oxidative damage in the brain?," Biochemical and Biophysical Research Communications, vol. 326, no. 4, pp. 794-798, 2005.

[9] M. A. Eghbal, P. S. Pennefather, and P. J. O'Brien, " $\mathrm{H}_{2} \mathrm{~S}$ cytotoxicity mechanism involves reactive oxygen species formation and mitochondrial depolarisation," Toxicology, vol. 203, no. 13, pp. 69-76, 2004.

[10] D. H. Truong, M. A. Eghbal, W. Hindmarsh, S. H. Roth, and P. J. O'Brien, "Molecular mechanisms of hydrogen sulfide toxicity," Drug Metabolism Reviews, vol. 38, no. 4, pp. 733-744, 2006.

[11] J. Jiang, A. Chan, S. Ali et al., "Hydrogen sulfide-mechanisms of toxicity and development of an antidote," Scientific Reports, vol. 6, no. 1, 2016.

[12] S. Miller, S. W. Walker, J. R. Arthur et al., "Selenite protects human endothelial cells from oxidative damage and induces thioredoxin reductase," Clinical Science, vol. 100, no. 5, pp. 543-550, 2001.

[13] R. S. Lymbury, M. J. Marino, and A. V. Perkins, "Effect of dietary selenium on the progression of heart failure in the ageing spontaneously hypertensive rat," Molecular Nutrition \& Food Research, vol. 54, no. 10, pp. 1436-1444, 2010. 
[14] S. J. Fairweather-Tait, Y. Bao, M. R. Broadley et al., "Selenium in human health and disease," Antioxidants and Redox Signaling, vol. 14, no. 7, pp. 1337-1383, 2011.

[15] J. Bleys, A. Navas-Acien, and E. Guallar, "Serum selenium and diabetes in U.S. adults," Diabetes Care, vol. 30, no. 4, pp. 829834, 2007.

[16] G. Deyab, I. Hokstad, J. Aaseth et al., "Effect of anti-rheumatic treatment on selenium levels in inflammatory arthritis," Journal of Trace Elements in Medicine and Biology, vol. 49, pp. 91-97, 2018.

[17] R. A. Heller, J. Seelig, T. Bock et al., "Relation of selenium status to neuro-regeneration after traumatic spinal cord injury," Journal of Trace Elements in Medicine and Biology, vol. 51, pp. 141-149, 2019.

[18] Clark, Dalkin, Krongrad et al., "Decreased incidence of prostate cancer with selenium supplementation: results of a double-blind cancer prevention trial," British Journal of Urology, vol. 81, no. 5, pp. 730-734, 1998.

[19] S. M. Lippman, E. A. Klein, P. J. Goodman et al., "Effect of selenium and vitamin $\mathrm{E}$ on risk of prostate cancer and other cancers," JAMA, vol. 301, no. 1, pp. 39-51, 2009.

[20] M. Vinceti, T. Filippini, C. Del Giovane et al., "Selenium for preventing cancer," Cochrane Database of Systematic Reviews, no. 3, Article CD005195, 2014.

[21] N. Karunasinghe, S. Zhu, and L. R. Ferguson, "Benefits of selenium supplementation on leukocyte DNA integrity interact with dietary micronutrients: a short communication," Nutrients, vol. 8, no. 5, p. 249, 2016.

[22] J. Lü, J. Zhang, C. Jiang, Y. Deng, N. Özten, and M. C. Bosland, "Cancer chemoprevention research with selenium in the postSELECT era: promises and challenges," Nutrition and Cancer, vol. 68, no. 1, pp. 1-17, 2016.

[23] J. K. Wrobel, R. Power, and M. Toborek, "Biological activity of selenium: revisited," IUBMB Life, vol. 68, no. 2, pp. 97-105, 2016.

[24] R. R. Ramoutar and J. L. Brumaghim, "Effects of inorganic selenium compounds on oxidative DNA damage," Journal of Inorganic Biochemistry, vol. 101, no. 7, pp. 1028-1035, 2007.

[25] C. Jiang, H. Hu, B. Malewicz, Z. Wang, and J. Lü, "Seleniteinduced p53 ser-15 phosphorylation and caspase-mediated apoptosis in LNCaP human prostate cancer cells," Molecular Cancer Therapeutics, vol. 3, no. 7, pp. 877-884, 2004.

[26] J. Lu, M. Kaeck, C. Jiang, A. C. Wilson, and H. J. Thompson, "Selenite induction of DNA strand breaks and apoptosis in mouse leukemic L1210 cells," Biochemical Pharmacology, vol. 47, no. 9, pp. 1531-1535, 1994.

[27] J. J. An, K. J. Shi, W. Wei et al., "The ROS/JNK/ATF2 pathway mediates selenite-induced leukemia NB4 cell cycle arrest and apoptosis in vitro and in vivo," Cell Death and Disease, vol. 4, no. 12, 2013.

[28] G. Nilsonne, X. Sun, C. Nyström et al., "Selenite induces apoptosis in sarcomatoid malignant mesothelioma cells through oxidative stress," Free Radical Biology and Medicine, vol. 41, no. 6, pp. 874-885, 2006.

[29] S. Biswas, G. Talukder, and A. Sharma, "Chromosome damage induced by selenium salts in human peripheral lymphocytes," Toxicology In Vitro, vol. 14, no. 5, pp. 405-408, 2000.

[30] J. Brozmanová, D. Mániková, V. Vlčková, and M. Chovanec, "Selenium: a double-edged sword for defense and offence in cancer," Archives of Toxicology, vol. 84, no. 12, pp. 919-938, 2010.
[31] E. Jablonska and M. Vinceti, "Selenium and human health: witnessing a Copernican revolution?," Journal of Environmental Science and Health, Part C, vol. 33, no. 3, pp. 328-368, 2015.

[32] S. Koike, Y. Ogasawara, N. Shibuya, H. Kimura, and K. Ishii, "Polysulfide exerts a protective effect against cytotoxicity caused by $t$-buthylhydroperoxide through Nrf2 signaling in neuroblastoma cells," FEBS Letters, vol. 587, no. 21, pp. 3548-3555, 2013.

[33] W. H. Sun, F. Liu, Y. Chen, and Y. C. Zhu, "Hydrogen sulfide decreases the levels of ROS by inhibiting mitochondrial complex IV and increasing SOD activities in cardiomyocytes under ischemia/reperfusion," Biochemical and Biophysical Research Communications, vol. 421, no. 2, pp. 164-169, 2012.

[34] P. Nagy, Z. Pálinkás, A. Nagy, B. Budai, I. Tóth, and A. Vasas, "Chemical aspects of hydrogen sulfide measurements in physiological samples," Biochimica et Biophysica Acta (BBA) - General Subjects, vol. 1840, no. 2, pp. 876-891, 2014.

[35] U. Samuni, Y. Samuni, and S. Goldstein, "On the distinction between nitroxyl and nitric oxide using nitronyl nitroxides," Journal of the American Chemical Society, vol. 132, no. 24, pp. 8428-8432, 2010.

[36] A. Misak, L. Kurakova, E. Goffa et al., "Sulfide $\left(\mathrm{Na}_{2} \mathrm{~S}\right)$ and polysulfide $\left(\mathrm{Na}_{2} \mathrm{~S}_{2}\right)$ interacting with doxycycline produce/scavenge superoxide and hydroxyl radicals and induce/inhibit DNA cleavage," Molecules, vol. 24, no. 6, p. 1148, 2019.

[37] D. Grundy, "Principles and standards for reporting animal experiments in The Journal of Physiology and Experimental Physiology," Journal of Physiology, vol. 593, no. 12, pp. 25472549, 2015.

[38] S. Cacanyiova, A. Berenyiova, F. Kristek, M. Drobna, K. Ondrias, and M. Grman, "The adaptive role of nitric oxide and hydrogen sulphide in vasoactive responses of thoracic aorta is triggered already in young spontaneously hypertensive rats," Journal of Physiology and Pharmacology, vol. 67, no. 4, pp. 501-512, 2016.

[39] L. Tomasova, M. Pavlovicova, L. Malekova et al., "Effects of AP39, a novel triphenylphosphonium derivatised anethole dithiolethione hydrogen sulfide donor, on rat haemodynamic parameters and chloride and calcium $\mathrm{Ca}_{\mathrm{V}} 3$ and $\mathrm{RyR} 2$ channels," Nitric Oxide, vol. 46, pp. 131-144, 2015.

[40] A. Kharma, M. Grman, A. Misak et al., "Inorganic polysulfides and related reactive sulfur-selenium species from the perspective of chemistry," Molecules, vol. 24, no. 7, 2019.

[41] K. A. Cupp-Sutton and M. T. Ashby, "Biological chemistry of hydrogen selenide," Antioxidants, vol. 5, no. 4, 2016.

[42] X. Pan, X. Song, C. Wang et al., "H2Se induces reductive stress in HepG2 cells and activates cell autophagy by regulating the redox of HMGB1 protein under hypoxia," Theranostics, vol. 9, no. 6, pp. 1794-1808, 2019.

[43] C. L. Bianco, T. A. Chavez, V. Sosa et al., "The chemical biology of the persulfide (RSSH)/perthiyl (RSS.) redox couple and possible role in biological redox signaling," Free Radical Biology and Medicine, vol. 101, pp. 20-31, 2016.

[44] D. J. O'Brien and F. B. Birkner, "Kinetics of oxygenation of reduced sulfur species in aqueous solution," Environmental Science \& Technology, vol. 11, no. 12, pp. 1114-1120, 1977.

[45] K. L. Nuttall and F. S. Allen, "Kinetics of the reaction between hydrogen selenide ion and oxygen," Inorganica Chimica Acta, vol. 91, no. 4, pp. 243-246, 1984. 
[46] G. W. Luther, A. J. Findlay, D. J. MacDonald et al., "Thermodynamics and kinetics of sulfide oxidation by oxygen: a look at inorganically controlled reactions and biologically mediated processes in the environment," Frontiers in Microbiology, vol. 2, 2011.

[47] J. M. Fukuto, S. J. Carrington, D. J. Tantillo et al., "Small molecule signaling agents: the integrated chemistry and biochemistry of nitrogen oxides, oxides of carbon, dioxygen, hydrogen sulfide, and their derived species," Chemical Research in Toxicology, vol. 25, no. 4, pp. 769-793, 2012.

[48] S. S. Saund, V. Sosa, S. Henriquez et al., "The chemical biology of hydropersulfides (RSSH): chemical stability, reactivity and redox roles," Archives of Biochemistry and Biophysics, vol. 588, pp. 15-24, 2015.

[49] H. Zhao, J. Joseph, H. Zhang, H. Karoui, and B. Kalyanaraman, "Synthesis and biochemical applications of a solid cyclic nitrone spin trap: a relatively superior trap for detecting superoxide anions and glutathiyl radicals," Free Radical Biology and Medicine, vol. 31, no. 5, pp. 599-606, 2001.

[50] J. E. Repine, O. W. Pfenninger, D. W. Talmage, E. M. Berger, and D. E. Pettijohn, "Dimethyl sulfoxide prevents DNA nicking mediated by ionizing radiation or iron/hydrogen peroxide-generated hydroxyl radical," Proceedings of the National Academy of Sciences, vol. 78, no. 2, pp. 1001-1003, 1981.

[51] M. Noda, Y. Ma, Y. Yoshikawa et al., "A single-molecule assessment of the protective effect of DMSO against DNA double-strand breaks induced by photo-and $\gamma$-ray-irradiation, and freezing," Scientific Reports, vol. 7, no. 1, 2017.

[52] S. Cacanyiova, A. Berenyiova, P. Balis et al., "Nitroso-sulfide coupled signaling triggers specific vasoactive effects in the intrarenal arteries of patients with arterial hypertension," Journal of Physiology and Pharmacology, vol. 68, no. 4, pp. 527-538, 2017.

[53] P. F. Dillon, R. S. Root-Bernstein, and C. M. Lieder, "Antioxidant-independent ascorbate enhancement of catecholamineinduced contractions of vascular smooth muscle," American Journal of Physiology-Heart and Circulatory Physiology, vol. 286, 2004

[54] M. Drobna, A. Misak, T. Holland et al., "Captopril partially decreases the effect of $\mathrm{H}_{2} \mathrm{~S}$ on rat blood pressure and inhibits $\mathrm{H}_{2} \mathrm{~S}$-induced nitric oxide release from S-nitrosoglutathione," Physiological Research, vol. 64, no. 4, pp. 479-486, 2015.

[55] S. S. Franklin, S. A. Khan, N. D. Wong, M. G. Larson, and D. Levy, "Is pulse pressure useful in predicting risk for coronary heart disease?," Circulation, vol. 100, no. 4, pp. 354-360, 1999.

[56] P. M. Mottram, B. A. Haluska, R. Leano, S. Carlier, C. Case, and T. H. Marwick, "Relation of arterial stiffness to diastolic dysfunction in hypertensive heart disease," Heart, vol. 91, no. 12, pp. 1551-1556, 2005.

[57] N. Geoffroy and G. P. Demopoulos, "The elimination of selenium(IV) from aqueous solution by precipitation with sodium sulfide," Journal of Hazardous Materials, vol. 185, no. 1, pp. 148-154, 2011.

[58] B. Jung, A. Safan, B. Batchelor, and A. Abdel-Wahab, "Spectroscopic study of Se(IV) removal from water by reductive precipitation using sulfide," Chemosphere, vol. 163, pp. 351-358, 2016.

[59] M. Pettine, F. Gennari, L. Campanella, B. Casentini, and D. Marani, "The reduction of selenium(IV) by hydrogen sulfide in aqueous solutions," Geochimica et Cosmochimica Acta, vol. 83, pp. 37-47, 2012.

[60] J. Hahn and R. Klünsch, "Synthesis and characterization of the first thiaselanes," Angewandte Chemie International Edition in English, vol. 33, no. 17, pp. 1770-1772, 1994.

[61] M. Grman, M. Nasim, R. Leontiev et al., "Inorganic reactive sulfur-nitrogen species: intricate release mechanisms or cacophony in yellow, blue and red?" Antioxidants, vol. 6, no. 1, 2017. 


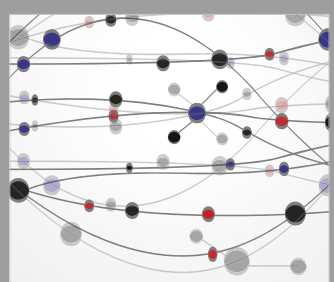

The Scientific World Journal
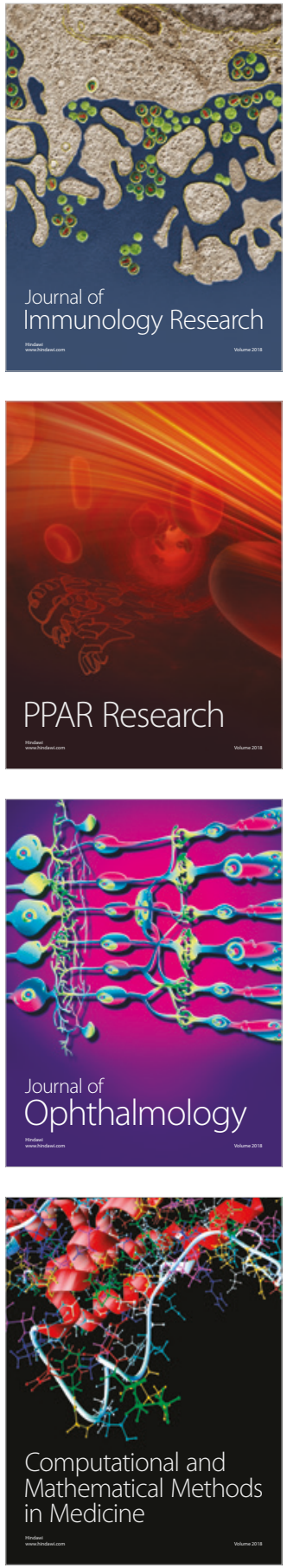

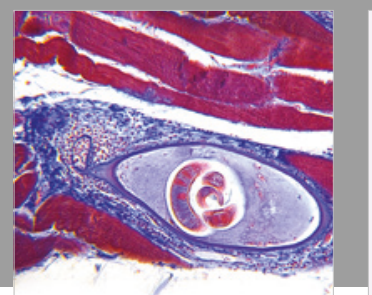

Gastroenterology Research and Practice

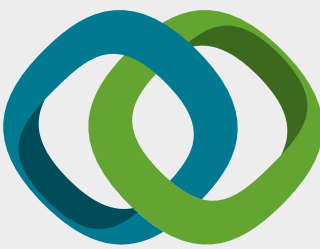

\section{Hindawi}

Submit your manuscripts at

www.hindawi.com
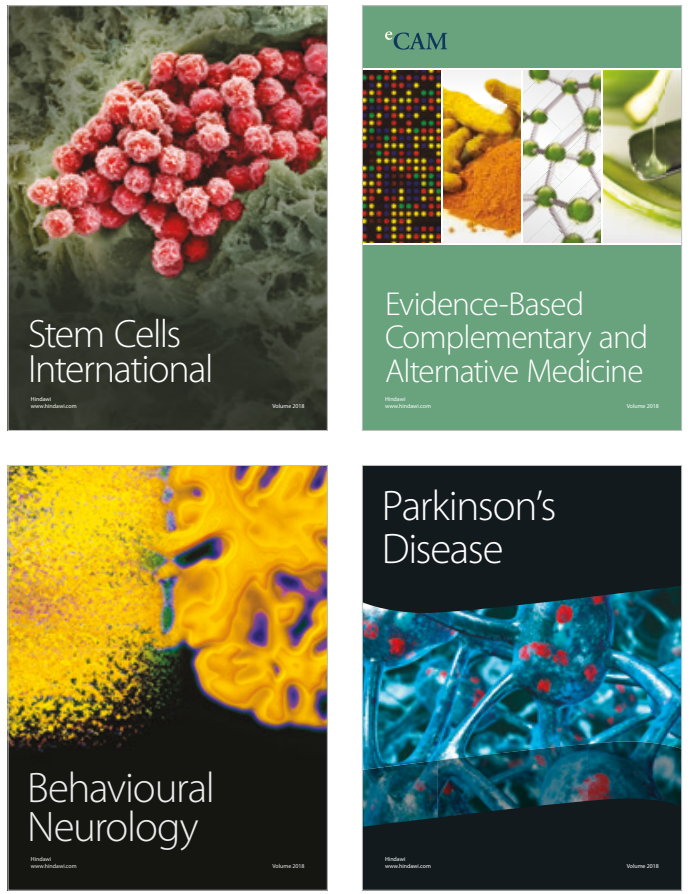

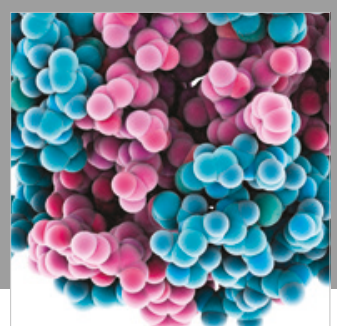

ournal of

Diabetes Research

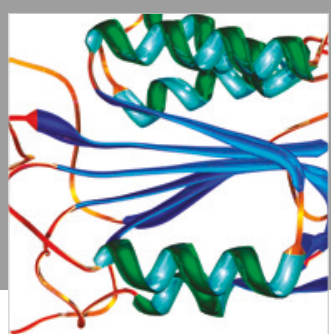

Disease Markers
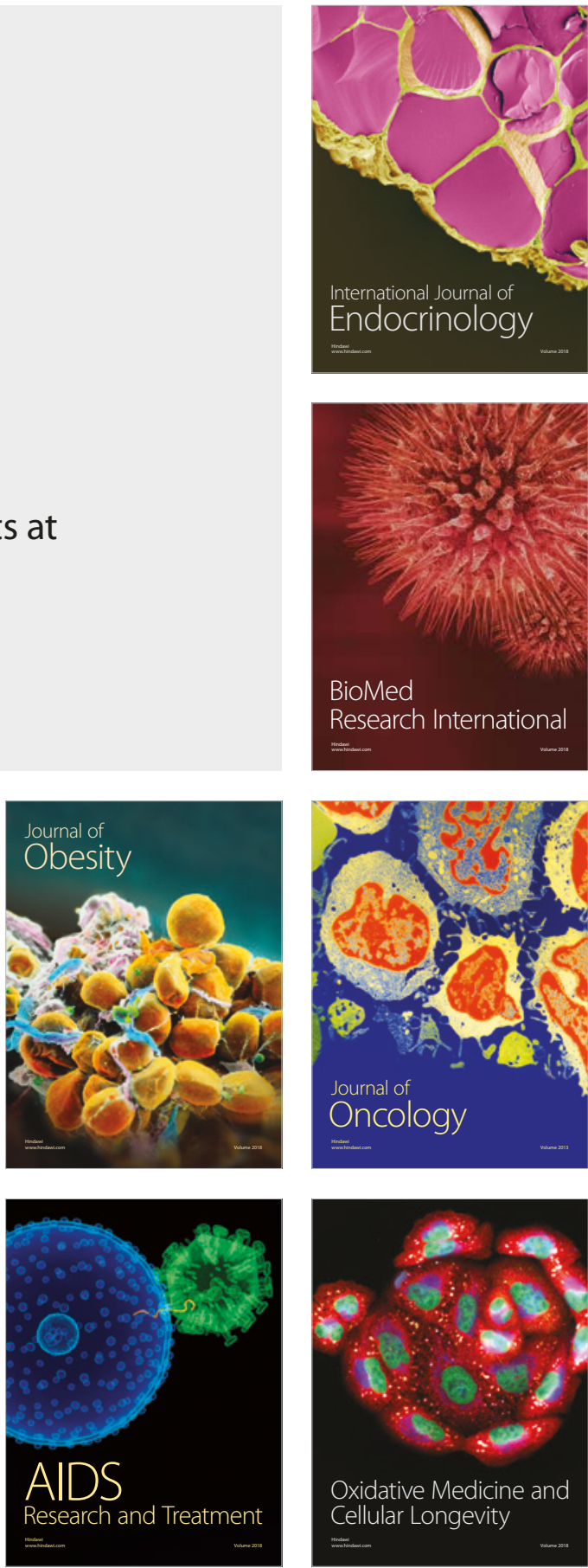